\title{
Integrated Landscape Change Analysis of Protected Areas and their Surrounding Landscapes: Application in the Brazilian Cerrado
}

\author{
Beatriz Bellón ${ }^{1,2, *} \mathbb{D}^{\text {, Julien Blanco }}{ }^{1}{ }^{\mathbb{C}}$, Alta De $\operatorname{Vos}^{2}{ }^{\mathbb{C}}$, Fabio de O. Roque ${ }^{3,4}$, Olivier Pays ${ }^{1,5}$ \\ and Pierre-Cyril Renaud ${ }^{1}$ (D) \\ 1 UMR CNRS 6554 LETG-Angers, UFR Sciences, Université d'Angers, 49045 Angers, France; \\ julien.blanco.pro@gmail.com (J.B.); olivier.pays@univ-angers.fr (O.P.); \\ pierre-cyril.renaud@univ-angers.fr (P.-C.R.) \\ 2 Department of Environmental Science, Rhodes University, Makhanda 6140, South Africa; a.devos@ru.ac.za \\ 3 Instituto de Biociências, Universidade Federal de Mato Grosso do Sul, Campo Grande, Mato Grosso do Sul \\ 79070-900, Brazil; roque.eco@gmail.com \\ 4 Centre for Tropical Environmental and Sustainability Science (TESS) and College of Science and Engineering, \\ James Cook University, Cairns, Queensland 4878, Australia \\ 5 LTSER France, CNRS, Hwange National Park, Dete, Zimbabwe \\ * Correspondence: bellon.beatriz@gmail.com; Tel.: +33-782-450-340
}

Received: 31 March 2020; Accepted: 28 April 2020; Published: 30 April 2020

\begin{abstract}
Remote sensing tools have been long used to monitor landscape dynamics inside and around protected areas. Hereto, scientists have largely relied on land use and land cover (LULC) data to derive indicators for monitoring these dynamics, but these metrics do not capture changes in the state of vegetation surfaces that may compromise the ecological integrity of conservation areas' landscapes. Here, we introduce a methodology that combines LULC change estimates with three Normalized Difference Vegetation Index-based proxy indicators of vegetation productivity, phenology, and structural change. We illustrate the utility of this methodology through a regional and local analysis of the landscape dynamics in the Cerrado Biome in Brazil in 2001 and 2016. Despite relatively little natural vegetation loss inside core protected areas and their legal buffer zones, the different indicators revealed significant LULC conversions from natural vegetation to farming land, general productivity loss, homogenization of natural forests, significant agricultural expansion, and a general increase in productivity. These results suggest an overall degradation of habitats and intensification of land use in the studied conservation area network, highlighting serious conservation inefficiencies in this region and stressing the importance of integrated landscape change analyses to provide complementary indicators of ecologically-relevant dynamics in these key conservation areas.
\end{abstract}

Keywords: conservation units; interface areas; landscape approach; land use and land cover change; vegetation dynamics; NDVI-based landscape metrics; MODIS time-series; Landsat

\section{Introduction}

Protected areas (PAs) currently cover around 15\% of the world's land and inland waters and remain the cornerstone of global biodiversity conservation strategies [1]. However, the capacity of PAs to preserve biodiversity greatly relies on the ability to maintain the ecological processes that span beyond their boundaries [2,3].

The anthropogenic-driven landscape dynamics in the PAs and surroundings (hereafter referred to as 'interface areas') highly influence the ecological processes that extend across these areas, such as those related to wildlife movement (e.g., population dynamics [4] or gene flows [5]), the ecosystem 
functions on which they rely, and the ecosystem services they provide [2,3]. These landscape dynamics can reflect both conservation efforts and the expansion and intensification of human land use, the latter being responsible for the largest negative impact on the conservation status of wildlife species worldwide [6].

To gain insight into the biodiversity status of interface areas and the effectiveness of conservation strategies and magnitude of anthropogenic pressures within them, it is critical to map and quantify the multiple spatiotemporal dimensions of landscape dynamics, and evaluate their relationship with different ecological processes and drivers of change. Yet, a recent review on the last 30 years of research on interface areas showed that only a low proportion of papers focused on landscape and habitat analyses [7]. The limited development of diversified and relevant indicators of landscape change for conservation biology research might partly explain the scarce landscape and habitat analyses in interface areas.

Although satellite remote sensing (SRS)-based methods allow scientists to derive a wide variety of environmental indicators for monitoring landscape dynamics, landscape change analyses in interface areas are currently mostly based on land use and land cover change (LULCC) indicators (e.g., [8-13]) and mainly assess changes in the surface area of forests, as an indicator of habitat loss (e.g., [14-17]). However, LULCC analysis does not allow scientists to derive indicators on changes in the state or biophysical conditions of the vegetation formations (e.g., forest aboveground biomass decline), which may be also relevant for conservation biology research.

In particular, changes in the phenology (seasonality), productivity, or structure of vegetation surfaces can have significant consequences for important ecological processes, ecosystem functions and services in interface areas (e.g., carbon cycle, resource availability, population dynamics, biological diversity, species distributions, and interactions) [18-20]. SRS vegetation indices (VI)-based landscape metrics allow scientists to locate and quantify the magnitude of these changes by providing proxy-estimates of phenology, productivity, and structural change. Moreover, VI-based landscape metrics can be relevant indicators of the indirect and direct factors driving these changes at different spatiotemporal scales (e.g., agricultural practices [21], selective logging [22], bush encroachment [23], rainfall/temperature regimes [24]). VI-based metrics can, therefore, improve the understanding of the major drivers of change in and around PAs and help locate and estimate the magnitude of their effects.

VI-based change detection can, therefore, complement LULCC analysis with fine-scale (pixel-level) estimates of potentially ecologically relevant changes, especially in areas that cannot be monitored using only LULCC analysis (i.e., areas where the LULC type remains unchanged). VI-based change detection is, however, rarely used in combination with LULCC in landscape change analysis and is still underused to assess landscape dynamics in interface areas, although some studies have shown its valuable contribution to conservation effectiveness (e.g., [25,26]), biodiversity (e.g., [19]), and ecosystem functioning (e.g., [27]) assessments.

The main objective of this paper is to introduce a two-step methodology to perform integrated landscape change analyses of interface areas using complementary SRS change detection methods. First, LULC data is used to analyze the major landscape composition changes, and second, three VI-based metrics based on MODIS and Landsat data are used to analyze the productivity, phenology, and structure changes of different natural and anthropogenic vegetation areas where the cover type has remained unchanged. This study also aims to fill a knowledge gap on the landscape dynamics of the Cerrado Biome's interface areas, a critical conservation area network on which we apply the methodology to perform a regional analysis, complemented by a local case study analysis.

Integrated landscape change analyses, like the one presented here, offer large-scale spatially explicit information on the different types and magnitude of changes experienced both by native vegetation remnants and the surrounding transformed surfaces. They therefore represent a valuable tool to improve the monitoring capacity of the landscape dynamics in interface areas. 


\section{Materials}

\subsection{Study Areas and Period}

The Brazilian Cerrado Biome is home to a large number of species and is characterized by a high level of endemism [28]. It is also highly vulnerable to habitat change, having experienced large-scale landscape transformation over the last decades, especially due to the fast expansion of cattle ranching and crop farming areas [29,30]. Between 2001 and 2013, the Cerrado Biome has lost its natural vegetation at an approximate rate of $0.41 \%$ (i.e., 772,000 ha) per year, while pastureland and cropland have increased by $11 \%$ [31]. Despite this pressure, environmental laws and policies remain less restrictive than in the neighboring Atlantic Forest and Amazon biomes [32].

We selected the Cerrado Biome's PAs (both core conservation units (hereafter, CUs) (Section 2.1.1) and buffer zones (hereafter, BZs) (Section 2.1.2) as an illustrative case study for a regional-level landscape change analysis, due to their critical role in preserving one of the world's biodiversity hotspots from the threats it is facing [28] and the little knowledge available on the LULC conversion types and vegetation dynamics (other than the proportion of native vegetation loss (e.g., [33,34])) in these areas. One of these CUs, the Parque Estadual das Nascentes do Rio Taquari, and its BZ were additionally used as an illustrative local case study to highlight the usefulness of our methodology in a spatially explicit way and within a more specified context.

We carried out the landscape change analysis over two years, 2001 and 2016. This two-year study period meets the following criteria: i) it allows a long-term analysis of landscape dynamics using homogeneous or analogous datasets (i.e., the same type of LULC and satellite data, presented in Sections 2.2 and 2.3, could be used for monitoring both years), which enables a more robust analysis; and ii) the two analyzed years did not present rainfall anomalies (Appendix A presents the rainfall anomalies analysis).

\subsubsection{Conservation Units}

The Brazilian National System of Conservation Units considers 12 different categories of PAs, classed into two major groups: five categories of CUs with a 'strictly protected' status, where biodiversity conservation is the main objective, and seven categories of CUs with a 'sustainable use' status, where resource exploitation is allowed in addition to biodiversity conservation objectives [35].

In our study we focused on the $61 \mathrm{CUs}$ belonging to the Cerrado Biome (as registered by the official managing agencies and bodies in the Brazilian National Register of Conservation Units [36]) designated before 2001 and classified as 'strictly protected'. A complete list of the 61 CUs retained for this study and their characteristics are presented in Appendix B. Most of the spatial boundaries of the 61 CUs were acquired from the official spatial layer 'Conservation Units of Brazil' of the Brazilian Ministry of Environment [37]. Since spatial boundaries were missing for the Parque Estadual Gruta da Lagoa Azul, Parque Estadual de Mirador and Parque Estadual do Cerrado, we extracted or digitized them from alternative sources [38-40].

\subsubsection{Buffer Zones}

According to the current Brazilian legislation [41], all CUs, except 'environmental protection areas' and 'private natural heritage reserves' (APA and RPPN, for their respective Portuguese acronyms), must have a BZ, defined as "the surroundings of a CU, where human activities are subject to specific rules and restrictions, to minimize the negative impacts on the unit", which must be spatially delimited in the CUs' management plans. In addition, the National Environment Council's (CONAMA, for its Portuguese acronym) resolution on environmental licensing around CUs [42] defined $10 \mathrm{~km}$ BZs around CUs, where any activity that may affect the biota must be licensed and authorized by the governmental agency responsible for the CU's management. However, due to the reactions from the productive sector [43], the legal resolution of CONAMA ( $\left.\mathrm{n}^{\circ} 13 / 90\right)$ was modified 20 years later with resolutions $\mathrm{n}^{\circ} 428$ [44] and $\mathrm{n}^{\circ} 473$ [45], which reduce the $10 \mathrm{~km}$ radius $\mathrm{BZ}$ to $3 \mathrm{~km}$. 
Since $41 \%$ of the selected 61 CUs do not have, to date, an approved management plan (Appendix B), and a clear delimitation of the BZ is missing from the majority of management plans, we decided to use the $10 \mathrm{~km}$ radius as defined by the earlier, more restrictive, resolution for the delimitation of the BZs. Our resultant study areas extend over $90,747 \mathrm{~km}^{2}$, spanning across twelve Brazilian states. Figure 1 shows the location of the study areas, and Figure 2 shows the location and landscape in 2001 and 2016 of the local case study.
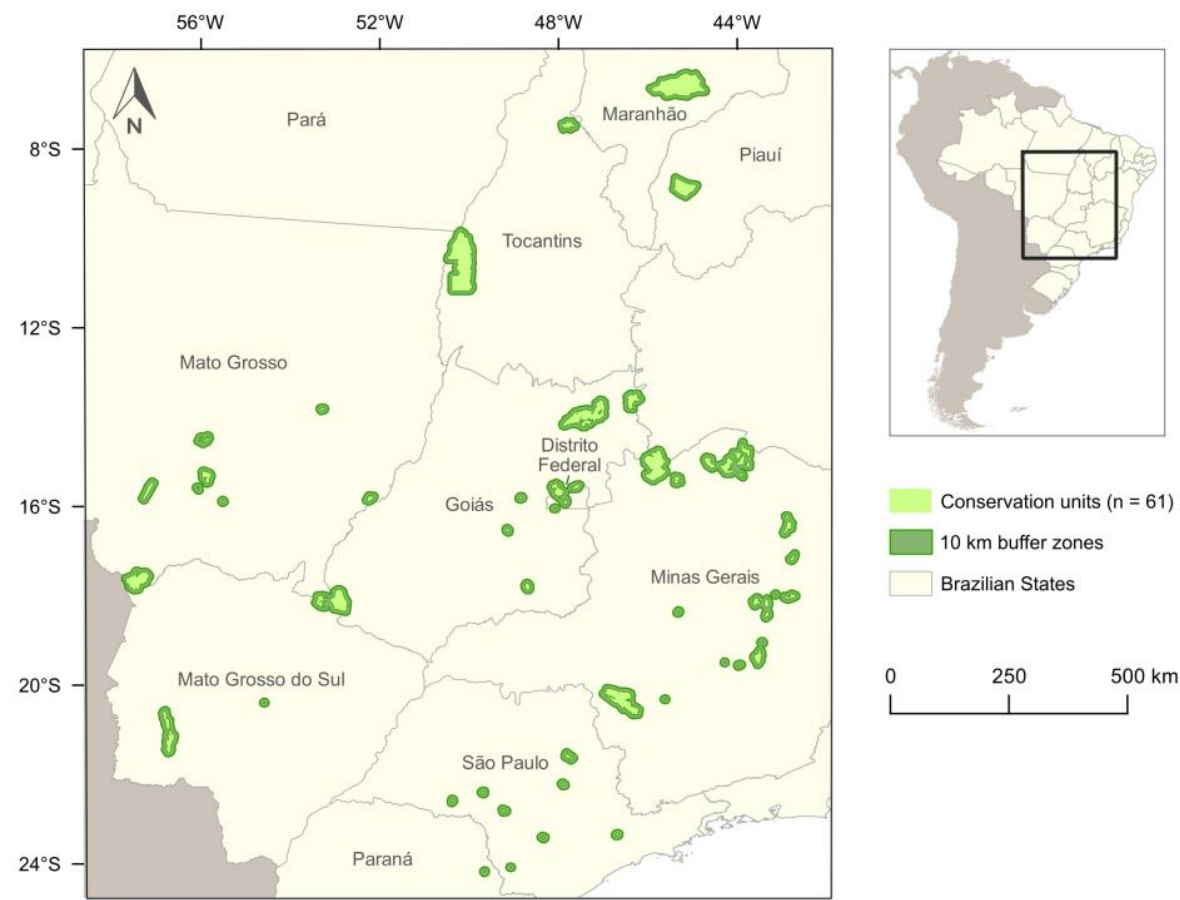

$\square 10 \mathrm{~km}$ buffer zones

Brazilian States

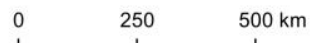

Figure 1. Location of the 61 'strictly protected' status conservation units selected for this study and their corresponding buffer zones.
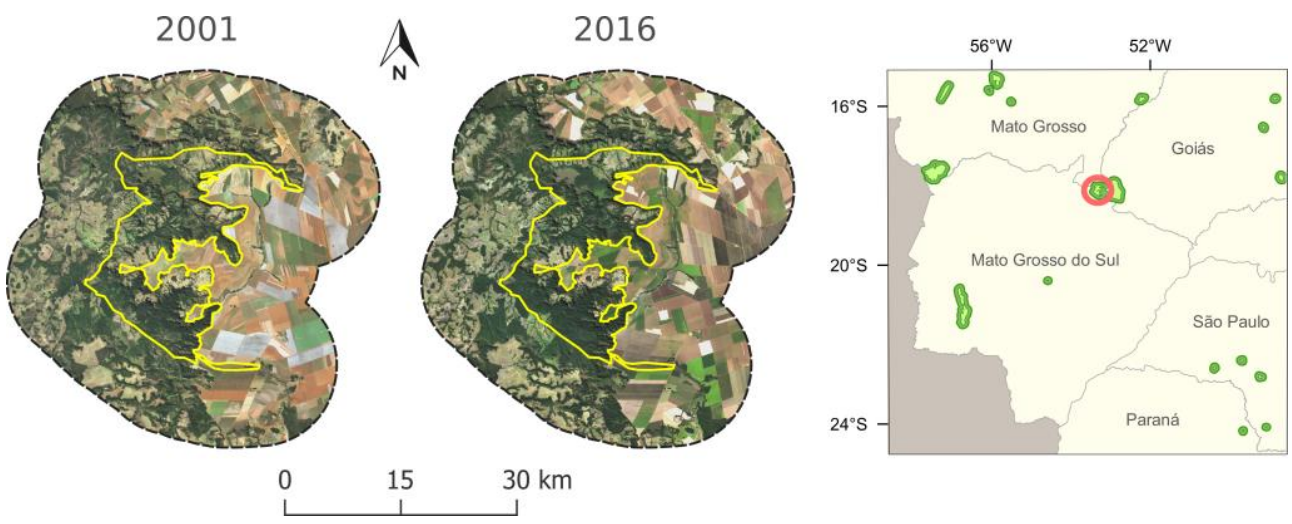

Figure 2. Red-Green-Blue composites of Landsat images (L7/ETM+ of the 09/07/2001 and L8/OLI of the 10/07/2016) showing the landscape of the Parque Estadual das Nascentes do Rio Taquari (boundaries are represented by the yellow outline), its $10 \mathrm{~km}$ buffer zone (boundaries are represented by the dashed black outline), and the location of the park (highlighted by the red circle).

\subsection{Land Use and Land Cover Data}

The land use and land cover (LULC) maps of 2001 and 2016 of the Brazilian Land Cover and Use Collection 4.0 Map Series of the MapBiomas project [46] were acquired for analyzing land use and land cover changes (LULCC) in the study areas (presented in Section 3.1). The potential of these remote 
sensing-based maps to locate and quantify large-scale LULC changes remains largely unexplored by the scientific community, and only a few recent studies have attempted to do so (e.g., [47-50]).

These maps, produced at a $30 \mathrm{~m}$ spatial resolution over the entire Brazilian territory, are obtained through annual automatic processing and classification of Landsat imagery. For our study, we used the levels 2 and 3 of the 2001 and 2016 classifications (a detailed explanation of the processing chain and validation methods used can be found in [51], and the results of the accuracy assessment are presented in Table 1).

Table 1. Results of the accuracy assessment of the levels 2 and 3 of the 2001 and 2016 classifications of Collection 4.0 MapBiomas land use and land cover maps (for information on quantity and allocation disagreement statistics see [52]).

\begin{tabular}{ccccc}
\hline \multirow{2}{*}{ Accuracy Statistics } & \multicolumn{2}{c}{ 2001 } & \multicolumn{2}{c}{2016} \\
\cline { 2 - 5 } & Level 2 & Level 3 & Level 2 & Level 3 \\
\hline Overall accuracy (\%) & 88.1 & 85.7 & 87.6 & 85.4 \\
Quantity disagreement (\%) & 2.6 & 4.1 & 3.5 & 4.5 \\
Allocation disagreement (\%) & 9.3 & 10.2 & 8.9 & 10.1 \\
\hline
\end{tabular}

We extracted the data corresponding to our study areas from the original raster maps, and, to provide a synthetic overview of the trajectories related to the main LULC types, we reclassified the original maps to create a simplified version containing ten categories of the original classification (Table 2). Due to pixels with missing values in the 2001 and/or 2016 layers, we were unable to analyze a total of $164 \mathrm{~km}^{2}$, which represents $0.18 \%$ of the study area.

Table 2. Three-level hierarchy of land use and land cover categories in the 2001 and 2016 MapBiomas Collection 4.0 maps ('Original classification') and the reclassified categories used in this study ('Final classification'). Only the categories present inside the study areas are included in the 'Original Classification' list.

\begin{tabular}{|c|c|c|c|}
\hline \multicolumn{3}{|c|}{ Original Classification } & \multirow{2}{*}{ Final Classification } \\
\hline Level 1 & Level 2 & Level 3 & \\
\hline \multirow{3}{*}{ 1. Forest } & \multirow{2}{*}{ 1.1. Natural Forest } & 1.1.1. Forest Formation & Natural Forest \\
\hline & & 1.1.2. Savanna Formation & Natural Forest \\
\hline & 1.2. Forest Plantation & - & Forest Plantation \\
\hline \multirow{4}{*}{$\begin{array}{l}\text { 2. Non-Forest Natural } \\
\text { Formation }\end{array}$} & 2.1. Wetland & - & Non-Forest Natural Formation \\
\hline & 2.2. Grassland & - & Non-Forest Natural Formation \\
\hline & 2.3. Rocky Outcrop & - & Other Non-Vegetated Area \\
\hline & $\begin{array}{l}\text { 2.4. Other Non-Forest } \\
\text { Natural Formation }\end{array}$ & - & Non-Forest Natural Formation \\
\hline \multirow{4}{*}{ 3. Farming } & 3.1. Pasture & - & Pasture \\
\hline & \multirow{2}{*}{ 3.2. Agriculture } & $\begin{array}{l}\text { 3.2.1. Annual and } \\
\text { Perennial Crop }\end{array}$ & Agriculture \\
\hline & & $\begin{array}{l}\text { 3.2.2. Semi-perennial } \\
\text { Crop }\end{array}$ & Agriculture \\
\hline & $\begin{array}{l}\text { 3.3. Mosaic of } \\
\text { Agriculture and Pasture }\end{array}$ & - & $\begin{array}{c}\text { Mosaic of Agriculture and } \\
\text { Pasture }\end{array}$ \\
\hline \multirow{3}{*}{ 4. Non-Vegetated Area } & 4.1. Urban Infrastructure & - & Urban Infrastructure \\
\hline & 4.2. Mining & - & Mining \\
\hline & $\begin{array}{l}\text { 4.3. Other } \\
\text { Non-Vegetated Area }\end{array}$ & - & Other Non-Vegetated Area \\
\hline 5. Water & $\begin{array}{l}\text { 5.1. River, Lake, and } \\
\text { Ocean }\end{array}$ & - & Water \\
\hline
\end{tabular}




\subsection{Satellite Data}

Part of our study aims to examine the vegetation dynamics of various vegetation cover types, including natural and anthropogenic vegetation cover. SRS vegetation indices have long been used for this purpose, the Normalized Difference Vegetation Index (NDVI) being the most widely used due to its strong relationship with vegetation biophysical parameters such as leaf area index, green leaf biomass, and leaf photosynthetic activity [53]. Although NDVI is affected by shadows, and is more affected by noise (e.g., aerosol effects) and by radiometric saturation over high biomass vegetation than other vegetation indices [54], it allows scientists to efficiently capture the vegetation dynamics of a wide range of vegetation cover types at short time scales. This is due to its high sensitivity to slight variations in the quantity and state of photosynthetic vegetation [55].

We used two different datasets of NDVI data: one dataset composed of MODIS time series, with a high temporal resolution to capture the vegetation dynamics at a fine temporal scale, and a complementary dataset consisting of high spatial resolution Landsat data. All the images were projected to the common Projected Coordinate System 'SIRGAS 2000/Brazil Polyconic (EPSG: 5880)'.

\subsubsection{MODIS Data}

Two annual time series of the MODIS Terra Vegetation Indices 16-Day Global $250 \mathrm{~m}$ product (MOD13Q1 v.5) [56] were obtained from the collection 'MODIS/MOD13Q1' of the Earth Engine Data Catalog through the Google Earth Engine (GEE) platform [57]. Although the MOD13Q1 version 6.0 collection extends the series of data beyond 2017 (when MOD13Q1 version 5.0 stopped being produced by the NASA Land Processes Distributed Active Archive Center), it currently presents issues related to "unexpected missing data, incorrect instances of No Data and spikes in the NDVI values and Usefulness band values not correctly assigned" (https://lpdaac.usgs.gov/products/mod13q1v006). We therefore downloaded the first and the last annual time series of the MOD13Q1 Version 5.0 product with a full-year coverage (23 composite images per year) for 2001 and 2016. This product is processed as 16-day syntheses of the daily surface reflectance series 'MOD09', and provides an NDVI band at 250 $\mathrm{m}$ resolution with minimized atmospheric and directional effects [56,58].

To reduce any potential remaining atmospheric effects, we applied the noise-reduction algorithm presented in [59] adapted from the iterative Savitzky-Golay smoothing algorithm developed by Chen et al. [60]. To ensure the noise reduction is also applied to the first and last images of the time series, we downloaded five extra images at both extremes of the two annual time series.

Finally, to linearly interpolate the smoothed time series pixel-wise, and place their values at regular intervals of 16 days, we used the Composite Day of Year (CDOY) band of the MOD13Q1 product, that contains the acquisition date of the pixels retained to produce the original composite images [56]. This step ensured a uniform sampling of the NDVI for each of the evaluated years. The different pre-processing steps applied to the MODIS data are shown in Figure 3.

To attain a valid NDVI range from 0.0 to 1.0 , a scale factor of 0.0001 was applied to all the bands in the 2001 and 2016 annual NDVI time series.

\subsubsection{Landsat Data}

We used Landsat data to obtain high spatial resolution images representing the landscapes of each CU and their BZs in 2001 and 2016. The choice of Landsat scenes was made according to these four criteria: 1 . Scenes had to be cloud-free over the studied areas; 2 . The number of scenes per CU and its corresponding BZ was minimized; 3 . If multiple scenes were needed to cover a CU and its $\mathrm{BZ}$, the dates of acquisition between scenes needed to be the closest possible in time; 4 . For the same CU and BZ, the acquisition date of the 2001 scene(s) needed to be the closest possible in time to the acquisition date of the 2016 scene(s). 


\section{DATA COLLECTION}

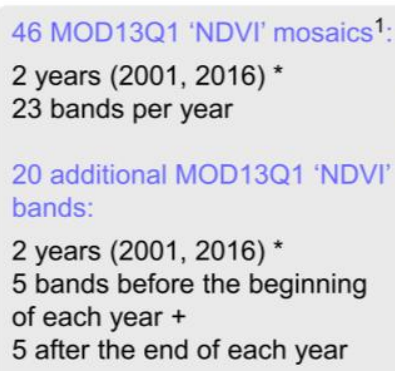

PREPROCESSING

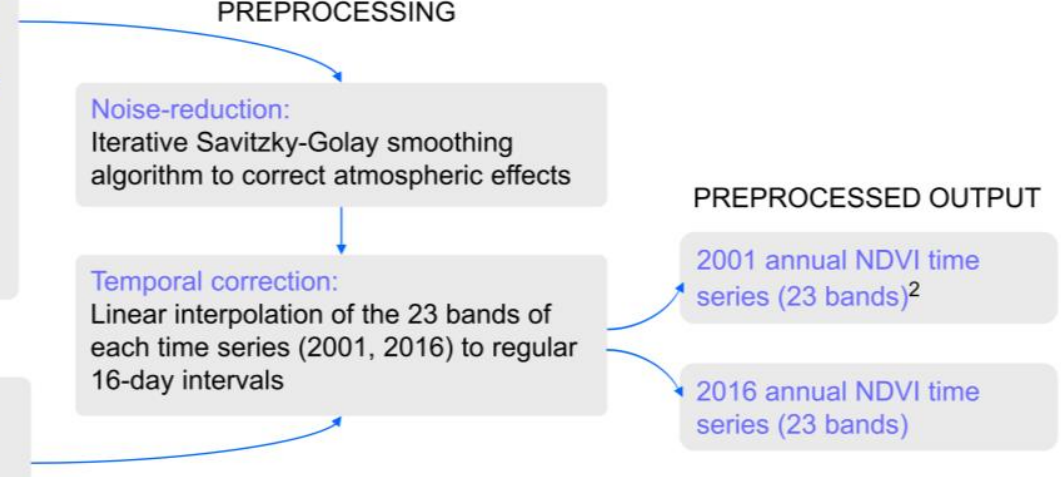

Figure 3. MODIS data collected and preprocessing steps. ${ }^{1}$ The original data derives from 5 MODIS tiles h12v10, h12v11, h13v09, h13v10, h13v11, which have been cropped to the extent of the study areas and mosaicked to a single image mosaic per date (i.e., 23 mosaics per year). ${ }^{2}$ The final annual time series start and end on the day-of-year 1 and 353, respectively.

A total of 113 scenes were selected (the acquisition details and identification of the Landsat scenes are presented in Appendix C). Since no single Landsat mission was operational in both 2001 and 2016 (except for the Landsat 7 mission in which, however, the Enhanced Thematic Mapper Plus (ETM+) sensor is failing since 2003 [61]), the scenes were selected from three missions and sensors of the Landsat Data Continuity Mission: Landsat 5 Thematic Mapper (TM) and Landsat 7 ETM+ scenes for the year 2001 and Landsat 8 Operational Land Imager (OLI) scenes for 2016.

Despite the inherent differences between the three sensors due to the design improvements and adjustments between successive missions, the latest Tier-1 Surface Reflectance collections are considered suitable for time-series analysis since they include the Landsat scenes with the highest available data quality, which are consistent and inter-calibrated across the different Landsat instruments [62-64].

The Near-Infrared (NIR) and Red (R) bands of the selected scenes were retrieved through the GEE platform from the following collections:

- $\quad$ Landsat 5 TM Tier-1 Surface Reflectance Collection ('LANDSAT/LT05/C01/T1_SR'), Band 3 (R), Band 4 (NIR);

- $\quad$ Landsat 7 ETM+ Tier-1 Surface Reflectance Collection ('LANDSAT/LE07/C01/T1_SR'), Band 3 (R), Band 4 (NIR);

- $\quad$ Landsat 8 OLI TM Tier-1 Surface Reflectance Collection ('LANDSAT/LC08/C01/T1_SR'), Band 4 (R), Band 5 (NIR).

In the GEE cloud-computing platform, the NDVI was subsequently computed from the NIR and Red bands of the 113 scenes that share a common spatial resolution of $30 \mathrm{~m}$, and were mosaicked to a single 2001 Landsat TM/ETM+ mosaic and a 2016 Landsat OLI mosaic. Finally, the mosaics were cropped to a $300 \mathrm{~m}$ buffer from the study areas' limits (to avoid edge effects when calculating the landscape metric related to the spatial variability of NDVI, presented in Section 3.2).

\section{Methods}

\subsection{Land Use and Land Cover Change Analysis}

The reclassified 2001 and 2016 MapBiomas LULC maps (Section 2.2) were used to determine the LULC transitions in the study areas (presented in Section 4.1.1). The analysis was carried out from pixel-area estimates and separately for the CUs (total area evaluated $=2,755,413 \mathrm{ha}$ ) and BZs (total area evaluated $=6,302,902 \mathrm{ha}$ ), by applying two widely used tools: 
- Transition matrices (also known as cross-tabulation matrices) [65,66], in which each row represents the LULC category in 2001, each column the LULC category in 2016, each entry represents the surface area experiencing LULCC or maintaining the same LULC type, and the last column and row represent the total area covered by each LULC category in 2001 and 2016, respectively.

- Sankey diagrams $[67,68]$, derived from the transition matrices, in which the total area covered by each LULC category in 2001 and 2016 is represented as stacked vertical bars (the height of each bar representing the relative proportion of each LULC type in the study areas), and in which transition lines, connecting each sequential pair of bars, represent the surface area experiencing LULCC or maintaining the same LULC type (the thickness of each line is proportional to the total surface area experiencing the corresponding LULC transition or remaining unchanged). The 'sankeyNetwork' function of the 'networkD3' R package v.0.4. $[69,70]$ was used to derive the Sankey diagrams.

\subsection{Vegetation Change Analysis}

To analyze the vegetation dynamics of the major vegetation cover types (i.e., 'Natural Forest', 'Non-Forest Natural Formation', 'Pasture', and 'Agriculture'), we first extracted the pixels belonging to these vegetation cover types in both years from the 2001 and 2016 MapBiomas LULC maps (i.e., the areas where the vegetation cover type remained unchanged).

To assess the dynamics of each vegetation cover type separately (i.e., measuring the "within-class" dynamics) and considering that the landscape metrics used for this purpose are calculated at the MODIS spatial resolution of $250 \mathrm{~m}$, we narrowed down the analysis to exclusively 'pure pixels' (i.e., $250 \mathrm{~m}$ resolution pixels with a uniform vegetation cover type).

To this end, the mask of "unchanged vegetation cover type pixels" at the original MapBiomas $30 \mathrm{~m}$ resolution was overlapped by a regular square-grid fitting the $250 \mathrm{~m}$ resolution MODIS cells. The grid cells overlapping different vegetation cover types' pixels or any missing values were used as a mask, applied to all of the satellite imagery to discard 'mixels' and missing values for subsequent analysis. By doing this, we avoided the mixed signals from cells covering heterogeneous vegetation types and ensured that the observed vegetation dynamics corresponded exclusively to the targeted vegetation types under evaluation. A total of 438,348 cells, equivalent to approximately $27,397 \mathrm{~km}^{2}$ were retained for the vegetation change analysis.

The masked satellite imagery was used to calculate the following three NDVI-based landscape metrics that provide complementary information on the spatiotemporal dynamics of the four major vegetation cover types.

A first landscape metric $\left(N D V I_{\text {inter }}\right)$ was derived from the 2001 and 2016 annual MODIS NDVI time series to evaluate the magnitude and overall trend of the inter-annual change of the four vegetation cover types. This first landscape metric was calculated pixel-wise as the difference between the annual mean NDVI in 2016 and 2001 (Figure 4a shows a schematic representation of the calculation of $N D V I_{\text {inter }}$ ):

$$
N D V I_{\text {inter }}\left(X_{t}, X_{0}\right)=\bar{X}_{t}-\bar{X}_{0}=\frac{1}{n} \sum_{i=1}^{n}\left(X_{t, i}-X_{0, i}\right)
$$

where $X_{0}$ and $X_{t}$ are the images in the first and last annual time series, respectively, and $n$ is the number of images in the annual time series. The valid range of $N D V I_{\text {inter }}$ is from -2 to 2 .

Considering that the NDVI is a well-established and widely-used spectral-based proxy for above-ground vegetation productivity (e.g., [71-76]), NDVI inter was therefore considered here as an indicator of vegetation productivity change: negative values represent areas where the mean annual productivity has decreased, and conversely, positive values indicate a general increase in the mean annual productivity. 


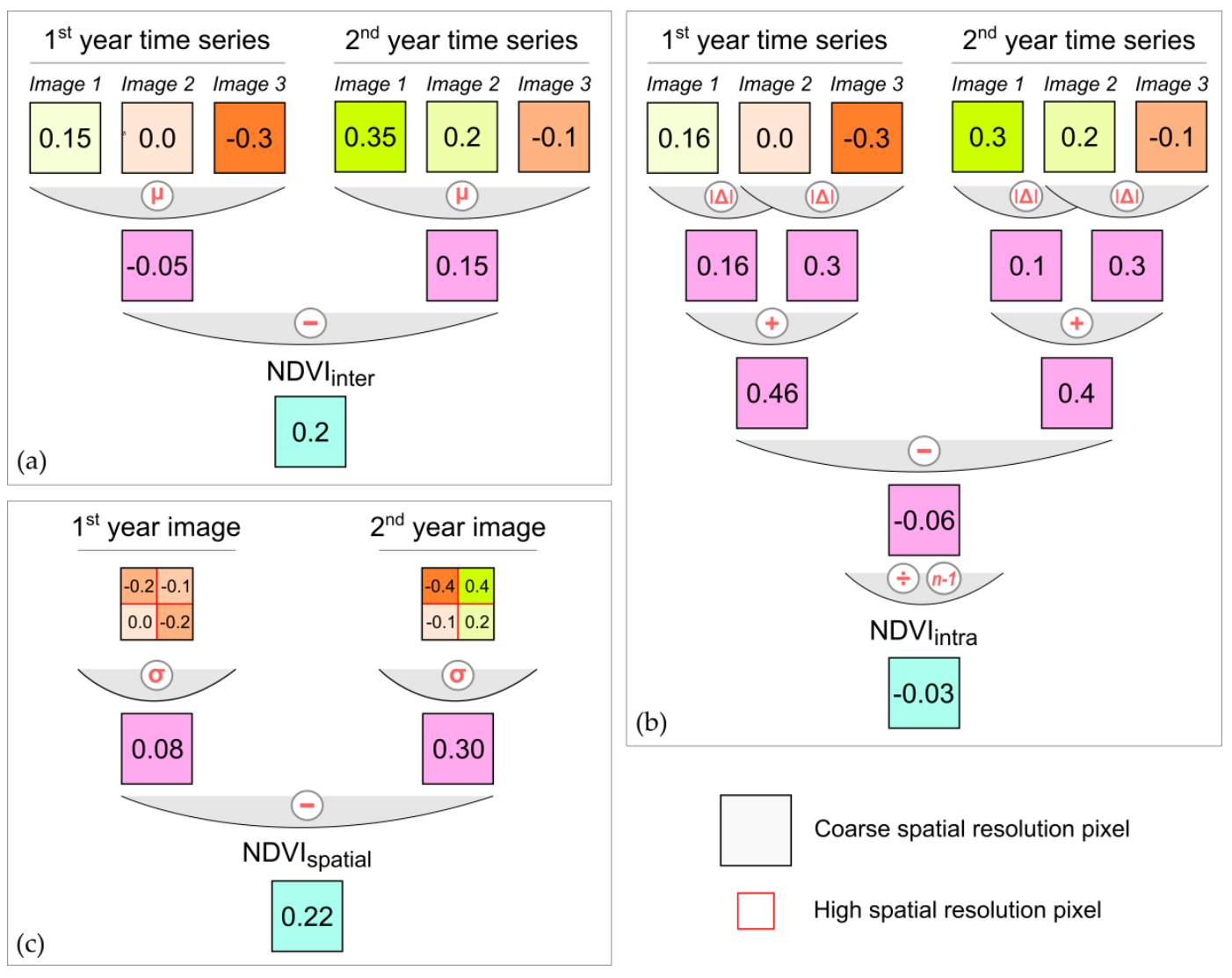

Figure 4. Schematic representation of the calculation of the three landscape metrics at the pixel level: (a) example of calculation of NDVIinter from two time series of three images each, where $\mu$ corresponds to the annual mean of the pixel values; (b) example of calculation of NDVIintra from two time series of three images each (i.e., $n=3$ ), where $|\Delta|$ corresponds to the absolute differences between each pair of consecutive images in the annual time series; (c) example of calculation of NDVIspatial from two high spatial resolution images (in this example a coarse-resolution pixel contains four high-resolution pixels), where $\sigma$ corresponds to the standard deviation of the high-resolution pixel values.

A second landscape metric (NDVI $I_{\text {intra }}$ ) was derived from the 2001 and 2016 annual MODIS NDVI time series to evaluate the magnitude and overall trend of the intra-annual variability change of the vegetation cover types.

We first calculated pixel-wise the cumulative intra-annual variations of NDVI in 2016 (i.e., the sum of the absolute differences between each pair of consecutive images in the annual time series), and divided the result by the number of sequential image pairs in the annual time series (i.e., 22) to obtain an average estimate of the intra-annual variability in 2016. We then repeated the same operation for the 2001 series and calculated the difference between the 2016 and 2001 results.

This second landscape metric was calculated pixel-wise as follows (Figure $4 \mathrm{~b}$ shows a schematic representation of the calculation of $\left.N D V I_{\text {intra }}\right)$ :

$$
N D V I_{\text {intra }}\left(X_{t}, X_{0}\right)=\frac{1}{n-1} \sum_{i=1}^{n-1}\left(\left|X_{t, i+1}-X_{t, i}\right|-\left|X_{0, i+1}-X_{0, i}\right|\right)
$$

where $X_{0}$ and $X_{t}$ are the images in the first and last annual time series, respectively, and $n$ is the number of images in the annual time series. The valid range of $N D V I_{\text {intra }}$ is from -2 to 2 .

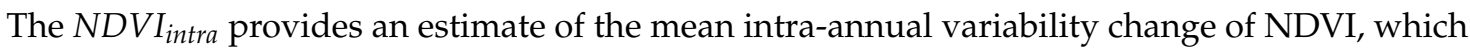
allows quantifying variations in the seasonal patterns of vegetation cover. Taking the definition of 'Land Surface Phenology', "the seasonal pattern of variation in vegetated land surfaces observed from 
remote sensing" [77], as a reference, the NDVI intra was considered here as an indicator of vegetation phenology change.

Unlike threshold-based or change-detection-based phenology metrics [78], NDVI intra $_{\text {does not aim }}$ to identify the changes in different phenological phases (e.g., start-of-season, green-up, peak of growing season, etc.) but rather to quantify the changes in the overall oscillatory pattern. For instance, negative values of $N D V I_{\text {intra }}$ indicate a decrease in the mean intra-annual variability of NDVI observations, due to either a decrease in the amplitude or the number of seasonal oscillations. Conversely, positive values indicate that seasonal oscillations have become more pronounced or numerous, therefore increasing the mean intra-annual variability.

A third landscape metric (NDVI spatial $)$ was derived from the 2001 Landsat TM/ETM+ and 2016 Landsat OLI mosaics to evaluate the magnitude and overall trend of the spatial variability change of the vegetation cover types.

We first spatially overlapped the Landsat images with the $250 \mathrm{~m}$ resolution grid and calculated the standard deviation of each set of Landsat pixels falling within each grid cell of 6.25 ha (i.e., approximately 64 Landsat pixels) for 2016 and 2001, separately. We then calculated pixel-wise the difference between the standard deviation values in 2016 and 2001. This allowed us to summarize the spatial NDVI variability change of the high-resolution Landsat data at the MODIS pixel size and bring this metric to a common spatial sampling scale with the other two metrics.

This third landscape metric was calculated as follows (Figure 4c shows a schematic representation of the calculation of $\left.N D V I_{\text {spatial }}\right)$ :

$$
\begin{gathered}
\operatorname{NDVI}_{\text {spatial }}\left(Y_{t}, Y_{0}\right)=\sigma\left(Y_{t}\right)-\sigma\left(Y_{0}\right) \\
\sigma\left(Y_{0}\right)=\sqrt{\frac{1}{n} \sum_{j=1}^{n}\left(Y_{0, j}-\bar{Y}_{0}\right)^{2}}
\end{gathered}
$$

where $Y_{0}$ and $Y_{t}$ are the set of high-resolution pixels within a coarse-resolution cell in the first and last year images, respectively, and $n$ is the number of high-resolution pixels that fit within a coarse-resolution cell. The valid range of $N D V I_{\text {spatial }}$ is from $\approx-1$ to $\approx 1$.

The landscape metric $N D V I_{\text {spatial }}$, which estimates the spatial variability change of NDVI, was used in this study as a proxy for vegetation structure change. Vegetation heterogeneity change (i.e., vegetation horizontal structure change) can be quantified through NDVI texture analysis techniques (e.g., [79-81]), which measure the variability of pixel values in a given area [82]. A highly heterogeneous vegetation cover, either in terms of the spatial distribution of plants or plant species composition therefore presents a high variability in NDVI, whereas a homogeneous vegetation cover will present a low variability [82].

The standard deviation of the NDVI in a given area provides a simple estimate of this spatial variability and has thus been used in previous studies to estimate the heterogeneity of different vegetation cover types (e.g., $[76,83,84]$ ) including landscapes in the Cerrado Biome from Landsat data $[85,86]$. Negative values in $N D V I_{\text {spatial }}$ therefore indicate a homogenization of the vegetation cover, and conversely, positive values depict areas that have become more heterogeneous.

The correlation between the three metrics for each vegetation cover type was calculated to test if the three metrics contribute with complementary and non-redundant information on the vegetation dynamics. The general trends of vegetation productivity, phenology, and structure change (as indexed by the landscape metrics) of each vegetation cover type at the regional level are presented in Section 4.1.2 and Appendix E. To facilitate their interpretation and determine any differences in the trends according to particular locations, their respective statistical distributions are represented in boxplots for the CUs and BZs, separately, and per Brazilian state. In addition, the local vegetation dynamics trends of the local case study are presented in Section 4.2. 


\section{Results}

\subsection{Regional-level Results}

\subsubsection{Land Use and Land Cover Change Analysis Results}

The LULC transition matrices of the 61 studied CUs and their BZs are presented in Appendix D and summarized in Table 3 and Figure 5.

Table 3. Absolute and relative change in surface area of the 10 land use and land cover (LULC) categories in the conservation units and their $10 \mathrm{~km}$ buffer zones between 2001 and 2016.

\begin{tabular}{ccccc}
\hline & \multicolumn{2}{c}{ Absolute Change in Surface Area (ha) } & \multicolumn{2}{c}{ Relative Change in Surface Area (\%) } \\
\cline { 2 - 5 } & Conservation Units & Buffer Zones & Conservation Units & Buffer Zones \\
\hline Natural Forest & $-14,851$ & $-132,858$ & -1.1 & -4.9 \\
Non-Forest Natural Formation & 14,676 & $-95,542$ & 1.3 & -7.0 \\
Forest Plantation & 545 & 57,248 & 40.1 & 71.4 \\
Pasture & $-17,765$ & $-152,747$ & -14.2 & -10.4 \\
Agriculture & 22,494 & 303,452 & 967.9 & 94.2 \\
Mosaic of Agriculture and Pasture & -320 & 2635 & -30.2 & 4.7 \\
Urban Infrastructure & 19 & 24,634 & 8.4 & 29.1 \\
Mining & 0 & 24 & 0.0 & 6.2 \\
Other Non-Vegetated Area & -2930 & -7625 & -9.4 & -8.4 \\
Water & -1868 & 779 & -5.2 & 0.8 \\
\hline
\end{tabular}

In total, the absolute surface area changes (considering loss and gain) in the CUs and BZs summed up to 75,468 ha and 777,544 ha, respectively, but a total of 348,463 ha in the CUs and 1,522,656 ha in the BZs experienced some type of LULCC from 2001 to 2016. These LULCC represent 12\% of the CUs' surface area and $24 \%$ of the BZs' surface area.

As shown in Figure 5a, the main LULCC that took place in CUs were changes between natural forests (i.e., natural savannah and forest formations) and non-forest natural formations (i.e., grassland and wetland vegetation formations). Accordingly, the natural vegetation (i.e., 'Natural Forest' and 'Non-Forest Natural Formation') inside CUs has experienced little absolute change in surface area between 2001 and 2016 (Table 3). Moreover, in CUs, a large amount of pastures evolved to natural vegetation in CUs (46,883 ha), and a large amount of natural vegetation in the CUs (51,787 ha) was transformed to farming land (i.e., 'Pasture', 'Agriculture', and 'Mosaic of Agriculture and Pasture'), mostly pastures (32,010 ha) but also agriculture (19,741 ha).

In BZs, the changes between natural forests and non-forest natural formations were also widespread (Figure 5b), but the most important LULCC (in number of hectares) was the conversion of natural forests to pastures (202,690 ha). This decline of natural forests in BZs has been considerably counterbalanced by a large amount of pastures being converted to natural forest $(167,162 \mathrm{ha})$. These relatively balanced and opposed conversions, which also took place between non-forest natural formations and pastures (Figure 5b), result in relatively little net loss in natural vegetation in the BZs (Table 3). Agriculture, on the other hand, experienced a considerable surface gain (Table 3). This important expansion of seasonal and perennial crops was mostly due to conversion of pastures, but there was also substantial conversion of natural vegetation to agriculture (Figure $5 b$ ).

In total, agriculture experienced the greatest expansion, and pastures experienced the greatest surface loss in both the CUs and the BZs, due, to a great extent, to their conversion to agriculture but mostly to natural vegetation (Table 3). Forest Plantations and Urban Infrastructures also expanded considerably in BZs (Table 3), however, since these, and other LULCC were relatively small in comparison with the aforementioned major transitions, further discussion will be focused on the results of the latter. 
(a) Conservation Units

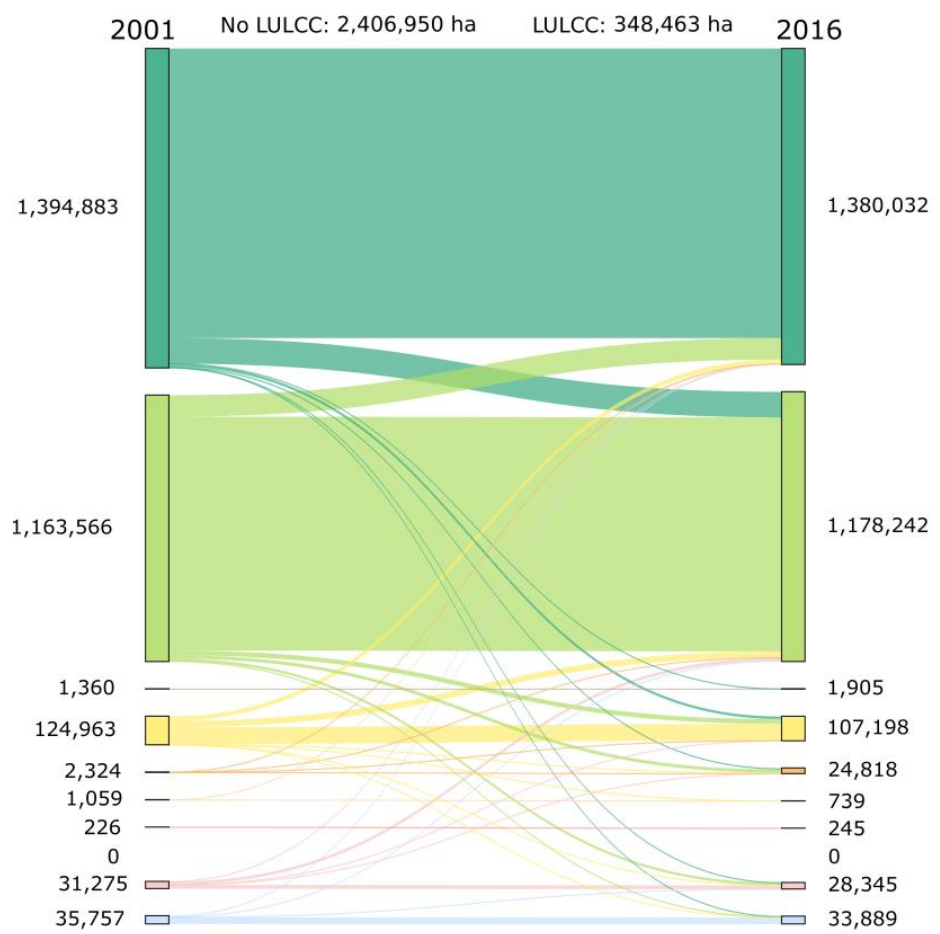

(b) Buffer Zones

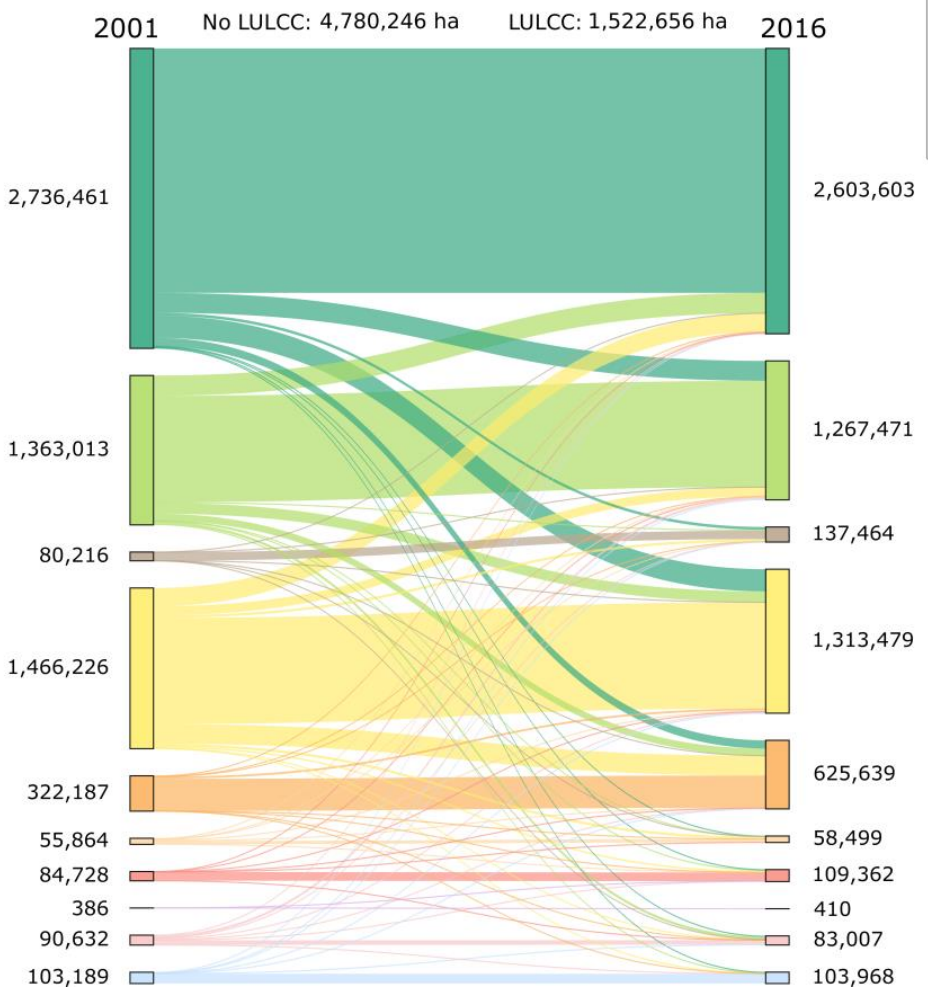

Natural Forest

Non-Forest Natural Formation

- Forest Plantation

Pasture

- Agriculture

Mosaic of Agriculture and Pasture

Urban Infrastructure

Mining

Other Non-Vegetated Area

Water

Figure 5. Sankey diagrams of the land use and land cover changes (LULCC) between 2001 and 2016 in (a) the conservation units and (b) their $10 \mathrm{~km}$ buffer zones. The values beside the nodes correspond to the number of hectares per LULC type in 2001 and 2016, respectively. Only the links representing transitions of more than 100 ha are shown. 
Despite the changes, the great majority of the surface in the study areas did not experience LULCC (Figure 5). The four major vegetation types (i.e., Natural Forest, Non-Forest Natural Formation, Pasture, and Agriculture) remained unchanged in $75 \%$ of the surface area $(6,821,747$ ha) between 2001 and 2016. For example, $90.6 \%$ of the natural forests in the CUs and $81.5 \%$ in the BZs did not experience LULCC, and $87.7 \%$ of the non-forest natural formations in the CUs and $71.2 \%$ in the BZs also remained unchanged.

\subsubsection{Vegetation Change Analysis Results}

Figure 6 shows the distribution of the three landscape metrics for the 438,348 cells retained for the vegetation change analysis (see Section 3.2). As expected, in all three cases, the actual empirical range of the metrics was considerably lower than their theoretical range (see Section 3.2), the latter being calculated considering maximal theoretical variability in NDVI, which is virtually impossible to reach in real conditions.

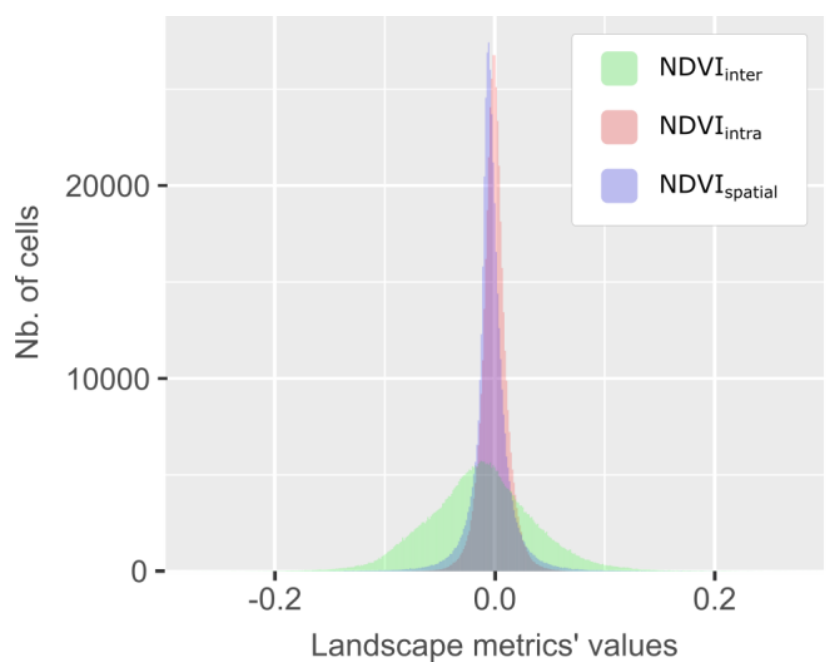

Figure 6. Histogram of the Normalized Difference Vegetation Index (NDVI)-based landscape metrics' values. Total number of cells $=438,348$.

Out of the analyzed cells, $57.3 \%$ belonged to natural forest areas, $27.3 \%$ to non-forest natural formations, $8.3 \%$ to pastures, and $7.1 \%$ to agricultural land. For the four vegetation types, no important relationships were found between the three landscape metrics: nearly all the landscape metrics pair-wise Pearson correlation coefficients $(r)$ were between -0.1 and 0.1 , except for the NDVI $I_{\text {intra }}$ and $N D V I_{\text {spatial }}$ correlation for the pastures, the $N D V I_{\text {inter }}$ and $N D V I_{\text {spatial }}$ correlation for the natural forests $(r=0.2)$, and the NDVI inter and $N D V I_{\text {intra }}$ correlation for the natural forests $(r=0.4)$. All correlations were statistically significant with a $p$-value $<0.001$. This suggests that each landscape metric provides complementary information on their vegetation dynamics.

To provide a concise overview of the regional-level vegetation dynamics' results, we only exhaustively present and discuss the results for the Natural Forest category. The results for the other three vegetation types are presented in Appendix E. The distributions of the landscape metrics' values for the Natural Forest are presented in Figure 7, for the whole study area (CUs and BZs, separately) and for each of the twelve Brazilian states (CUs and BZs combined). 

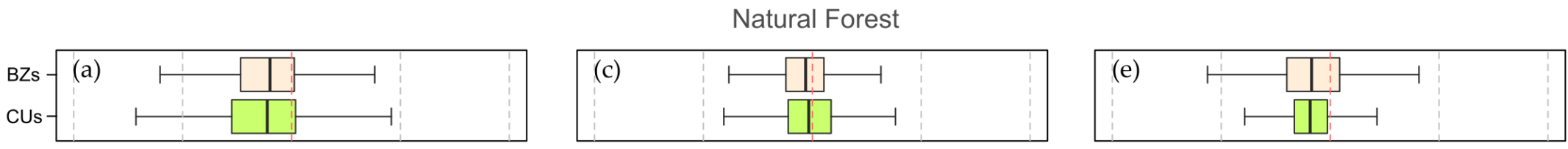

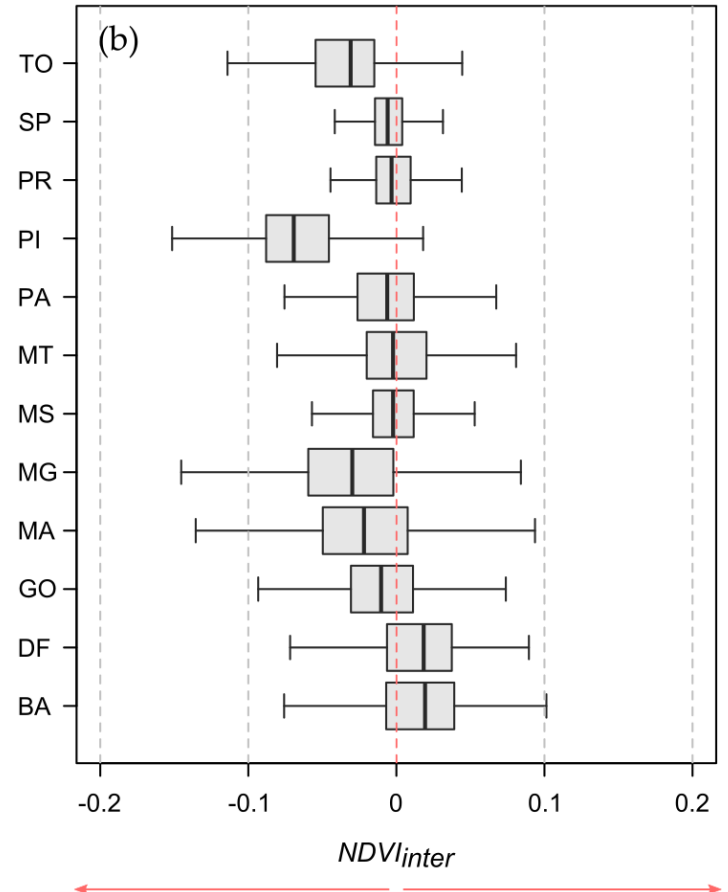

Less productive More productive

Vegetation productivity change

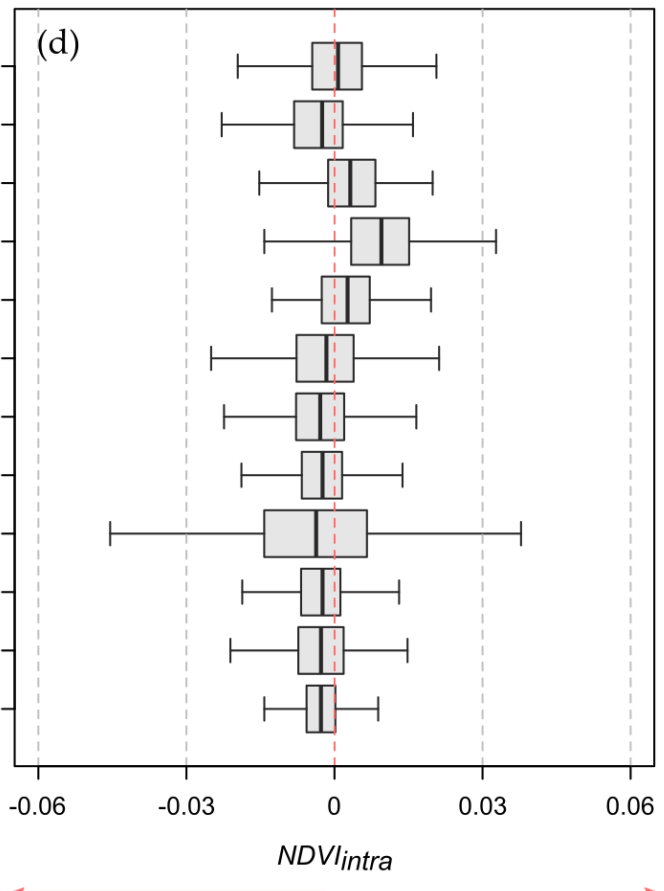

Less intra-annual variability More intra-annual variability

Vegetation phenology change

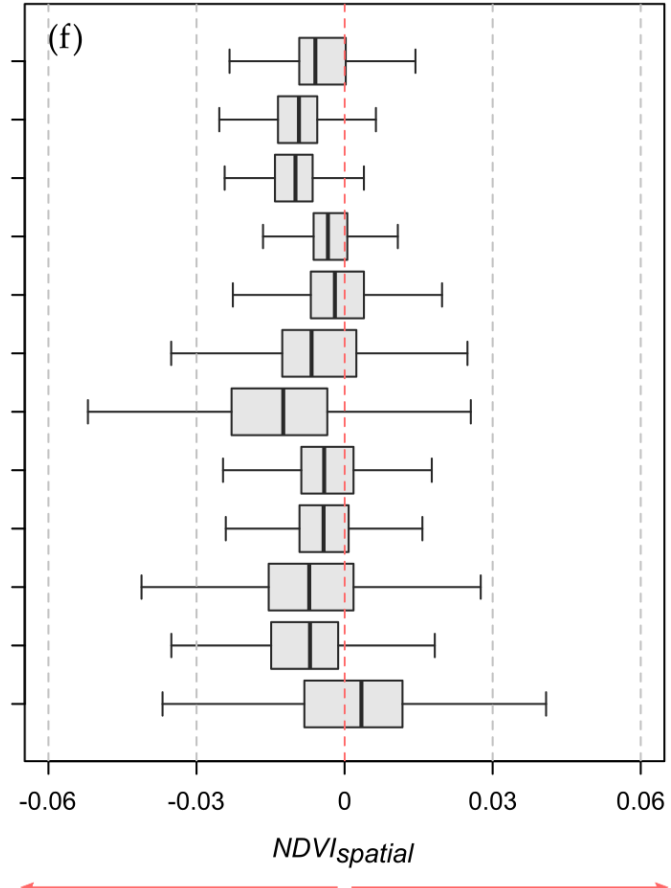

More homogeneous More heterogeneous

Vegetation structure change

Figure 7. Boxplots of the landscape metrics' values of the cells belonging to the 'Natural Forest' category: (a) $N D V I_{\text {inter }}$ in the buffer zones (BZs) and conservation units (CUs); (b) $N D V I_{\text {inter }}$ in each state; (c) $N D V I_{\text {intra }}$ in the BZs and CUs; (d) NDVI intra in each state; (e) $N D V I_{\text {spatial }}$ in the BZs and CUs; (f) $N D V I_{\text {spatial }}$ in each state. Number of $250 \mathrm{~m}$ resolution (6.25 ha) cells located inside the 61 conservation units $=209,714$ and in their buffer zones $=382,556$. Number of cells in each Brazilian state with n > 0: Tocantins (TO, 34,905), São Paulo (SP, 4,296), Paraná (PR, 220), Piauí (PI, 21,057), Pará (PA, 285), Mato Grosso (MT, 22,749), Mato Grosso do Sul (MS, 28,982), Minas Gerais (MG, 73,836), Maranhão (MA, 39,514), Goiás (GO, 22,063), Distrito Federal (DF, 2,305), Bahia (BA, 982). 


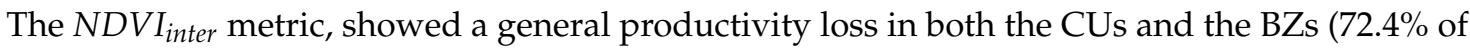
the analyzed Natural Forest cells in the BZs experienced a decrease in the annual average of NDVI and $71.9 \%$ in the CUs) (Figure 7a). This trend was widespread across the CUs and BZs of nearly all the states, except for Distrito Federal and Bahia (where nearly $70 \%$ of their Natural Forests experienced an increase in productivity), and was especially pronounced in the CUs and BZs of Piauí and Tocantins, where $96.3 \%$ and $89.3 \%$ of the natural forests have loss productivity (Figure $7 \mathrm{~b}$ ).

The NDVI intra metric showed a slight trend towards a more stable NDVI throughout the year for the natural forest areas $(59.7 \%$ and $54.7 \%$ of the analyzed area in the BZs and CUs, respectively, experienced a decrease in the intra-annual variability of NDVI) (Figure 7c). The natural forests located in the CUs and BZs of Bahia were the most representative of this trend (with $73.8 \%$ of the forests obtaining negative $N D V I_{\text {intra }}$ values), and on the other hand, the forests in Piauí followed a clear opposite trend ( $83 \%$ of the forests experienced an increased intra-annual variability of NDVI) (Figure 7d).

Furthermore, the general negative trend in the spatial variability of NDVI measured by NDVI spatial (Figure 7e) suggested that the canopy of natural forests was, in general, experiencing homogenization. This trend was followed by $96.8 \%$ and $92.4 \%$ of the forests in Paraná and São Paulo, respectively (Figure 7f). A relatively smaller proportion of the forests in the other states follow this trend, except for those in Bahia, which experienced the opposite trend at a larger proportion (i.e., the forest cover is becoming more heterogeneous) (Figure 7f).

\subsection{Local Case Study Results}

The Parque das Nascentes do Rio Taquari and its BZ are dominated by natural forest, pasture, and agriculture areas (Figure 8a). The great majority of these areas have not experienced LULCC between 2001 and 2016 (Figure 8b), except for some forested areas having been cleared and transformed into pasture (these areas, characterized by a loss in productivity, are highlighted by low NDVI inter values e.g., top zoom of Figure 8c). Nevertheless, the results of the three landscape metrics over the apparently stable areas show that different vegetation dynamics have taken place (Figure $8 \mathrm{c}-\mathrm{e}$ ). The three landscape metrics are represented in Figure 8 as a continuous gradient over all types of LULC (depicting both vegetation dynamics related to LULCC processes and other processes) but only the masked satellite imagery (Section 3.2) is analyzed.

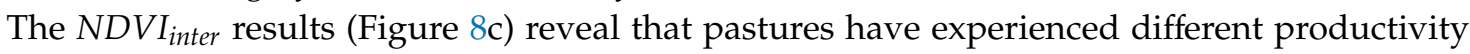
changes locally, $40.4 \%$ have increased their average annual NDVI while $59.6 \%$ have experienced loss in productivity (the bottom-left zoom shows an example of loss in average annual NDVI of nearly 0.1 ). Regarding forests, productivity trends also vary locally. As for agriculture, $N D V I_{\text {inter }}$ results (Figure 8c) show that the majority of areas $(67.6 \%$ ) have increased their productivity (as in the bottom-left zoom, where the mean annual NDVI has increased by nearly 0.2 ).

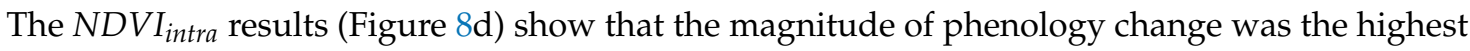
in the agricultural land, in both positive and negative directions. This result reflects a change in the number of annual crop cycles (shown in the zoom images and annual temporal profiles of NDVI in Figure $8 \mathrm{~d}$ ). High positive $N D V I_{\text {intra }}$ values (in red) thus reflect an increase in the number of cropping cycles and high negative values (in blue) show the opposite (Figure 8d).

The $N D V I_{\text {spatial }}$ results (Figure 8d) show an overall increase in the spatial variability of NDVI over the pasture land ( $68 \%$ of the pastures have positive $N D V I_{\text {spatial }}$ values, indicating a general increase in heterogeneity). They also show an overall decrease in the spatial variability over the agricultural areas, where $60.4 \%$ is becoming more homogeneous, despite the contrasted changes over the edges of the field plots (related to changes in their size and shape). However, the clearest trend reflected by the $N D V I_{\text {spatial }}$ metric concerns the homogenization of the forest cover (represented by negative values). This trend, which also represents the majority of forest areas at the regional level (Section 4.1.2), represents $92.5 \%$ of the forest in this local case study, and suggests general densification of the forest canopy (zoom image in Figure 8d). 

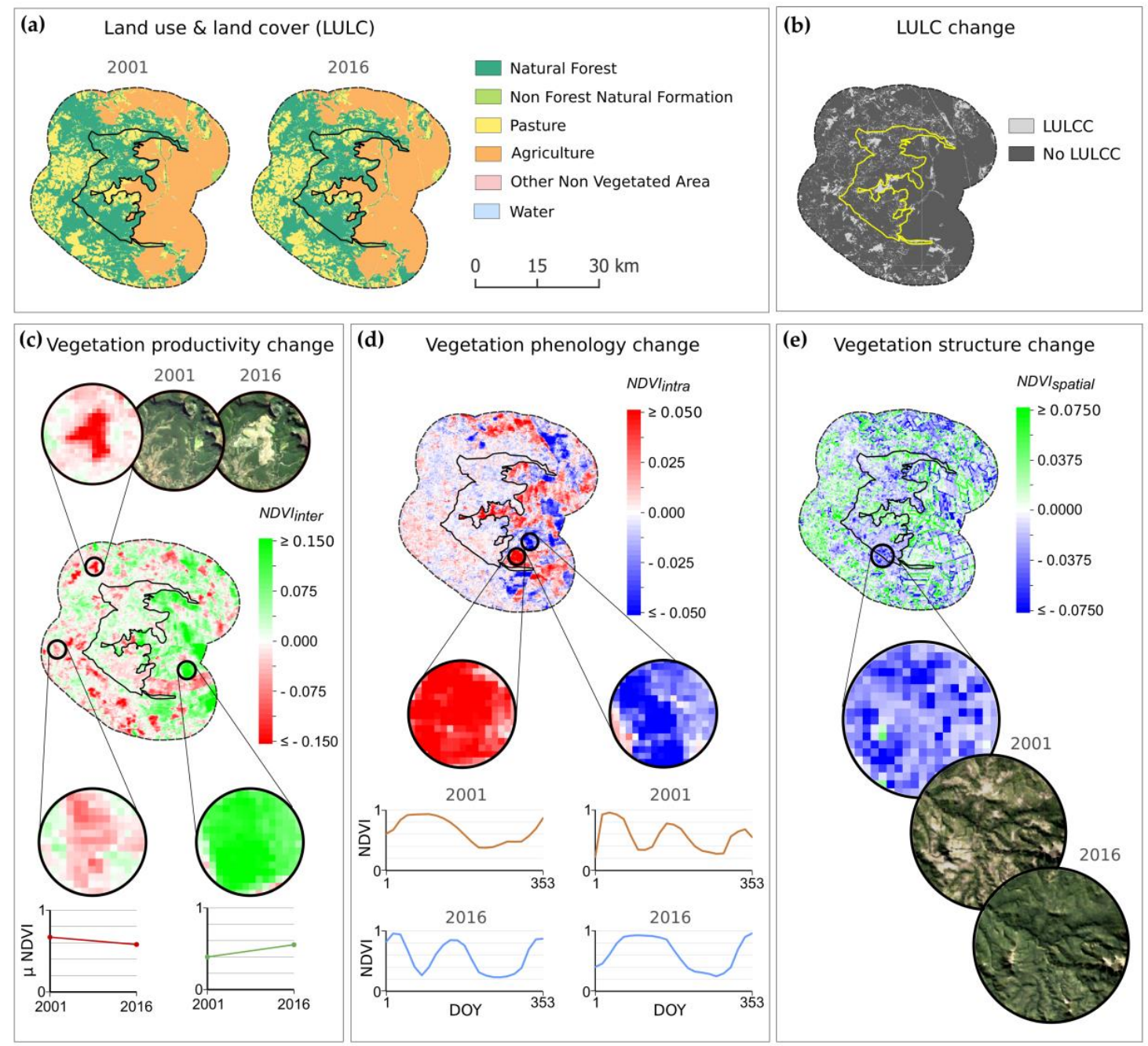

Figure 8. (a) Land use and land cover (LULC) in 2001 and 2016 at the Parque das Nascentes do Rio Taquari and its buffer zone; (b) LULC change map; (c) NDVI inter results. Top zoom image: decrease in productivity due to forest clearing. Bottom-left zoom image: decrease in productivity in pasture area. Bottom-right zoom image: increase in productivity in agricultural area. Plots: average annual NDVI in 2001 and 2016 of one of the pixels inside the above pasture and agricultural areas; (d) NDVI $I_{\text {intra }}$ results. Left zoom image: increase in intra-annual variability in agricultural area due to the increase in the number of crop cycles during the year. Right zoom image: opposite dynamic. Plots: profile of NDVI against the day-of-year (DOY) in 2001 and 2016 of one of the pixels inside the agricultural areas in the above zoom images; (e) $N D V I_{\text {spatial }}$ results. Zoom image: decrease in spatial variability reflecting densification of forest cover.

\section{Discussion}

Our study illustrates the potential of combining LULC change-detection with VI-based change-detection methods to derive spatially explicit and complementary information on the landscape changes taking place in PAs and their surrounding zones. Additionally, our combined approach has supplemented current knowledge of the Brazilian Cerrado's interface areas' landscape changes (e.g., $[33,34])$ with new information on the types of LULC and vegetation dynamics. We discuss these in Sections 5.1 and 5.2, and in Section 5.3, we address some operational and research perspectives of our work. 


\subsection{Land Use and Land Cover Change Analysis in the Cerrado Biome's Protected Areas and Buffer Zones}

The regional-level LULCC analysis showed relatively little net loss in native vegetation, (especially in the CUs) but underlying high levels of conversion, which raises concerns about the general conservation effectiveness of these core PAs and their legally managed BZs. The major LULC conversion between 2001 and 2016 in these areas, other than the conversion between different natural vegetation types, was related to the transformation of natural vegetation to farming land: 51,787 ha in the CUs, despite this conversion being forbidden in strictly protected CUs, and 446,155 ha in the BZs.

These natural habitats were mainly cleared to install new pastures for cattle ranching; however, the conversion to crops was also responsible for a non-negligible portion of the deforestation. Even if a nearly proportional amount of natural vegetation has increased over former pastures, especially in CUs, secondary savannas recovered from abandoned pastures hardly return to the biodiversity levels of old-growth savannas without active restoration interventions [87]. The proposed methodology allows us to locate these areas, but complementary in situ monitoring would be relevant to investigate how these areas are being managed and to assess their levels of biodiversity in comparison with old-growth savannas.

The LULCC results have also highlighted the fast expansion between 2001 and 2016 of agricultural land in the BZs (increase rate of 94\%) and to a lesser extent within the CUs limits (around 22,000 ha in 15 years). This result echoes the alarming rate of agricultural expansion in the Cerrado Biome as a result of increasing international demand for commodity crops $[29,88,89]$. Given that most areas in the BZs correspond to private landholdings, that a considerable proportion of the CUs has not been yet expropriated [90], and that many CUs still do not have approved management plans, this result may suggest that the regulation of the landowners' decisions to secure conservation targets in these areas has been greatly limited. Yet, considering the rate of habitat loss in the sustainable use CUs reported by Françoso et al. [34], the situation for the whole PA-network may be even worse than for the 61 strictly protected CUs investigated here.

Complementary assessments of these landscape dynamics through comparative analysis of the LULCC within interface areas and the rest of the Cerrado would provide further insight into the effectiveness of these areas to reduce landscape composition transformation as compared to unprotected land. Despite misclassifications, which are common in LULC data (especially between classes with similar spectral properties), the regular and open remote sensing-derived LULC datasets provided by the MapBiomas (https://mapbiomas.org/) and the TerraClass Cerrado [91] initiatives offer promising tools for this type of large-scale analyses.

\subsection{Contribution of the Vegetation Change Analysis}

The results of the vegetation change analysis offered complementary indications on environmental changes related to processes other than LULCC. Even if ground-surveys would ultimately be needed to explain the local biophysical processes behind the observed trends, some general hypotheses may be drawn from the main results.

The general Natural Forest productivity loss (as measured by the NDVI inter) in both in the CUs and BZs suggests a general decline in above-ground biomass, which could reflect a potential degradation of the savannah and forest ecosystems functions. Bustamante et al. [92] indicated that a decrease in the primary productivity of the Cerrado was expected due to the projected climate and fire-regime changes. Besides, the homogenization of the canopy cover, shown by the $N D V I_{\text {spatial }}$ results may reflect the natural progression of the Cerrado vegetation from open to more closed formations with a higher density of woody plants [93]. This pattern was observed in the local case study (Figure 8e) and may suggest a general natural evolution towards late successional stages and forest encroachment (e.g., [94]).

Furthermore, the local case study results have illustrated the potential of the landscape metrics to monitor subtle changes in farming areas in a spatially explicit way. For example, the metrics highlighted some dynamics that were also predominant at the regional level, such as a global increase 
in crop productivity (Figures $8 \mathrm{c}$ and A4b), and a prevalent homogenization of the agricultural land (Figures 8e and A4f), which may ultimately reflect a general intensification of the agricultural practices. Moreover, $N D V I_{\text {intra }}$ allowed to identify changes in the number of crop cycles (Figure $8 \mathrm{~d}$ ). This metric may, therefore, be relevant to identify areas with an increase in the number of annual cropping cycles, as a complementary indicator of intensification of cropping systems (e.g., $[95,96])$.

Finally, the results showed a particularly high dispersion of the landscape metrics in the BZ agricultural areas, as compared to the other evaluated vegetation types (Figure A4). This may indirectly reflect a wide variety of agricultural practices, which likely results in highly differentiated protected-area-agriculture interface landscapes. Additionally, the contrasting distributions per state of some landscape metrics (e.g., Figure A2b), show strong regional variability in the dynamics of certain vegetation types. To assess potential differences in the management of these areas (e.g., [34]), it is thus important to conduct comparative landscape change analyses at the state level, as well as by type of CU category or jurisdictional level.

\subsection{Perspectives for Future Research in Remote Sensing and Interface Areas}

Most studies on interface areas are still mostly using LULCC analysis to monitor landscape dynamics (e.g., [8-17]). By combining LULCC analysis with VI-based change detection, we were able to characterize LULCC and explore vegetation changes in areas where no LULCC was observed, thus offering complementary information. This complementarity was particularly evident in our studied areas, since $75 \%$ of the vegetation cover had not experienced LULCC during the study period, but had experienced changes in phenology, productivity, and structural changes. It was further evident in the local case study, where relatively little LULCC obscured substantial change in pastures, forests, and cropland.

Our methodology, therefore, offers a practical and promising avenue for producing more detailed assessments of landscape dynamics in interface areas. Integrated methodologies, such as the one presented, can provide a more complete picture of functional landscape changes, which can, in turn, improve our understanding about the links between landscape dynamics and ecological processes.

Beyond expanding the change detection capacity by allowing us to detect conditional change in addition to transitional change [97], the presented NDVI-based metrics also offer the advantages of pixel-based analyses. These advantages include temporal and spatial robustness, fine-scale observations and a gradient-based representation of landscapes (especially relevant for fine structure change detection [98]). However, unlike LULCC analysis, which provides simple and intuitive information, field surveys are required to obtain precise interpretations of the local processes behind observed vegetation dynamics. The NDVI-based metrics results can, nevertheless, help orientate field surveys to sample areas where particular vegetation dynamics are observed or over a gradient of dynamics to gain insight on the underlying social-ecological processes and their spatial distribution.

Through this procedure, NDVI-based metrics can offer valuable indications on some processes that may be relevant for ecological assessments such as habitat simplification and degradation, or intensification of agricultural practices. They can, therefore, help locate zones in the interface areas that could be potentially experiencing loss in ecological functionality or could be prone to future land conversion or degradation. This study, therefore, builds on the recent research exploring the use of SRS-derived products as indicators of ecosystem function [99-101] and Essential Biodiversity Variables (EBVs) [102-105] and could be potentially integrated into ecosystem services assessments [106], ecosystem models [107], species distribution models (e.g., [100,108,109]), movement ecology studies (e.g., [110]), and even social-ecological systems analyses (e.g., [111]).

From an operational point of view in the Brazilian context, this study shows the potential of using existing SRS-derived LULC maps from the MapBiomas project (https://mapbiomas.org/) to detect illegal deforestation within 'strictly protected' CUs. Alert systems such as the one proposed by the MapBiomas initiative could include analyses at the CUs level and BZs to offer an operational tool to alert the official managing agencies of these PAs. Moreover, the proposed methodology may 
represent a significant contribution to current information systems both in the interface areas in Brazil (where it could be implemented in monitoring systems of the Chico Mendes Institute for Biodiversity Conservation to complement in situ monitoring [112]), as well as in other world regions, since existing systems are still mostly focused on monitoring habitat loss in forest areas [13].

The new cloud-computing platform GEE [57] offers unprecedented computing possibilities that facilitate the reproduction of the proposed methodology. The applicability of the methodology and its broad-scale operationalization is, however, limited by the availability of appropriate input data. Especially, timely and reliable LULC maps must be available for the analysis, and while these products are increasingly available, they are still missing in many regions and require a high-investment to produce them. Additionally, the surface area over which the vegetation change analysis can be carried out is limited by the spatial resolution of the landscape metrics and the LULC data (e.g., in our study, a mask had to be applied to discard 'mixels' for the vegetation change analysis, due to the spatial resolution mismatch of landscape metrics at $250 \mathrm{~m}$ and LULC data at $30 \mathrm{~m}$ ).

In particular, the data from the Sentinel-2 constellation of the Copernicus program, which are available at $10 \mathrm{~m}$ spatial resolution and 5 days temporal resolution, from 2017 onwards, alone or in combination with other high spatial resolution data (e.g., [113]), are key products to overcome the limitations of 'mixel' issues and will allow the monitoring of landscape dynamics over a larger extent, including small, fragmented landscapes. Additionally, the new Landsat Tier-1 Collections [63,114] offer an unprecedented opportunity for high-resolution time-series analyses with the improved usability and consistency of the Landsat archives and could facilitate the upgrading of bi-temporal change detection to continuous monitoring through time series or trajectory analysis [97]. The proposed landscape metrics could provide valuable information on the exact timing of major landscape changes and on subtler changes in the ecosystems' conditions if they were calculated over successive years for multiple-year periods. However, to reveal any additional processing that may be required for time series analysis, studies evaluating the radiometric consistency of the vegetation indices and their spatial variability from one instrument to another are still needed (e.g., [115-118]).

\section{Conclusions}

This study illustrates the potential of combining SRS-derived LULC data and NDVI-based landscape metrics to obtain complementary, spatially explicit information on the landscape changes in protected areas and their surrounding landscapes (interface areas). The presented methodology allows the localization of major long-term land conversions in a network of interface areas in the Cerrado Biome and the detection of trends in the productivity, phenology, and structure changes of the major natural and anthropogenic vegetation cover types. This study allows us to fill a knowledge gap in this geographic region in particular and opens new perspectives of the analysis of interface areas in general. Ultimately, this work contributes to the development of satellite remote sensing tools to improve the monitoring capacity and guide and support conservation planning in key conservation areas.

Author Contributions: Conceptualization, B.B.; Methodology, B.B.; Validation, B.B., J.B. and P.-C.R.; Formal Analysis, B.B.; Writing-Original Draft Preparation, B.B.; Writing-Review \& Editing, B.B., J.B., A.D.V., F.d.O.R., O.P., P.-C.R.; All authors supervised the research and contributed to the editing and review of the paper. All authors have read and agreed to the published version of the manuscript.

Funding: This research was supported by the Pays de la Loire regional government (France) in the framework of the international research project CASEST (Anthropogenic Constraints to Tropical Social-Ecological Systems) as part of a Stratégie International grant, and by a Rhodes Council Grant. This work was also supported by a Google Faculty Research Grant and B.B. received a Rhodes University Postgraduate Scholarship.

Conflicts of Interest: The authors declare no conflict of interest. The funders had no role in the design of the study; in the collection, analyses, or interpretation of data; in the writing of the manuscript, or in the decision to publish the results. 


\section{Appendix A.}

The rainfall anomalies' analysis was performed with the historical data from the Meteorological Database for Teaching and Research (BDMEP) of the Brazilian National Institute of Meteorology (INMET) [119]. This database contains the data collected by the 'conventional meteorological stations' from the INMET stations network. The rainfall anomalies' analysis was carried out in 5 steps:

1. We collected the monthly total precipitation data $(\mathrm{mm})$ of the BDMEP meteorological stations that had a nearly complete 30 year time series of data from 1986 to 2016 (with no more than 1 consecutive month of missing records in the time series).

2. The data was transformed to spatial point data, using the meteorological stations' geographic coordinates, and the data from the meteorological stations closest to the 61 conservation units (CUs) analyzed in this study was retained: the data from a total of 36 meteorological stations, spanning from $60.0^{\circ} \mathrm{W}$ to $35.0^{\circ} \mathrm{W}$ and $0.1^{\circ} \mathrm{S}$ to $23.5^{\circ} \mathrm{S}$, was selected.

3. The missing data gaps in the time series were temporally interpolated with the average value of the previous and next months and the monthly data was aggregated to retrieve the annual total precipitation $(\mathrm{mm})$ for each year.

4. The Inverse Distance Weighting (IDW) algorithm implemented in the Interpolation Plugin of the Quantum GIS (QGIS) software [120] was then applied to the annual total precipitation data to obtain spatially continuous annual spatial interpolations over the whole study areas at a $5 \mathrm{~km}$ spatial resolution. The Zonal Statistics Plugin [120] was then used to extract the total annual precipitation values for the 30 year period for each CU centroid.

5. To evaluate the rainfall conditions in the two analyzed years (2001 and 2016), we used the climatological normal (i.e., the average value of a meteorological element over 30 years) as a reference base for the calculation of the Modified Rainfall Anomaly Index (mRAI) [121]. This index, based on the Rainfall Anomaly Index (RAI) developed by van Rooy (1965), is well adapted to short time periods of precipitation data [121], and thus to the length of our time series, and allows to classify the rainfall anomalies into 9 classes (Table A1).

Table A1. Classification of the Modified Rainfall Anomaly Index (mRAI).

\begin{tabular}{ccc}
\hline & mRAI Value & Description \\
\hline 1 & $\geq 2.00$ & Extremely wet \\
2 & 1.50 to 1.99 & Very wet \\
3 & 1.00 to 1.49 & Moderately wet \\
4 & 0.50 to 0.99 & Slightly wet \\
5 & -0.49 to 0.49 & Near normal \\
6 & -0.99 to -0.50 & Slightly dry \\
7 & -1.49 to -1.00 & Moderately dry \\
8 & -1.99 to -1.50 & Very dry \\
9 & $\leq-2.00$ & Extremely dry \\
\hline
\end{tabular}

The mRAI was calculated as follows:

$$
m R A I_{i}= \pm S F\left(P_{i}-\bar{P}\right) /(\bar{E}-\bar{P})
$$

where, $P_{i}$ is the total precipitation sum for the year $i, \bar{P}$ is the median of all annual precipitation sums of the 30 year period, $S F$ is the scaling factor of 1.7 for positive anomalies $\left(P_{i} \geq \bar{P}\right)$ and -1.7 for negative anomalies $\left(P_{i} \leq \bar{P}\right)$, and $\bar{E}$ is the mean of the $10 \%$ most extreme precipitation annual sums. For positive anomalies $\left(P_{i} \geq \bar{P}\right), \bar{E}$ is the mean of the annual precipitation sums of the 3 most rainy years of the 30 year period; for negative anomalies $\left(P_{i} \leq \bar{P}\right), \bar{E}$ is the mean of the annual precipitation sums of the 3 least rainy years of the 30 year period. 
The results show a significant positive correlation between the total annual rainfall in 2001 and 2016 for the 61 conservation units (Figure A1a), which suggests that both years received similar rainfall amounts. In addition, the two evaluated years present similar mRAI results (Figure A1b), both years being classed normal to moderately dry with regards to the 30 year period and thus do not present any extreme rainfall anomalies.

(a)

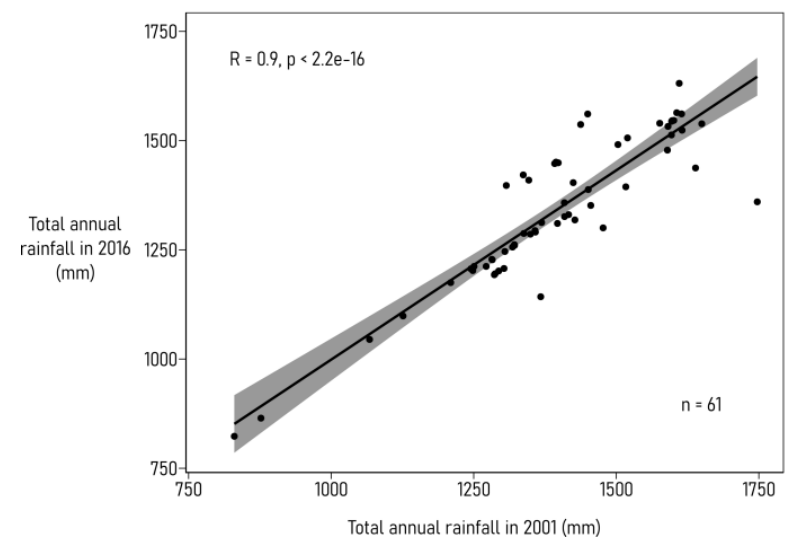

(b)

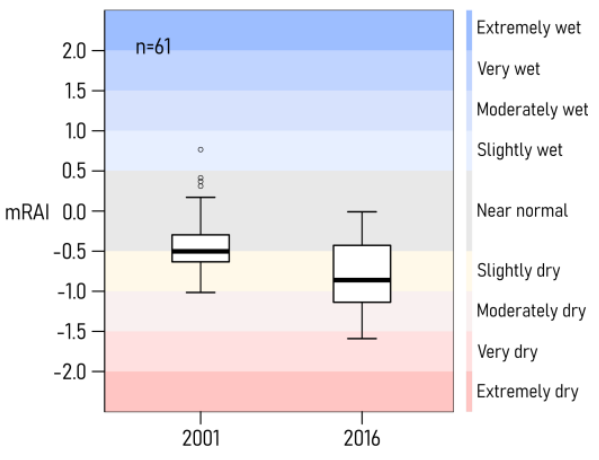

Figure A1. (a) Scatter plot showing significant positive linear correlation between the total annual rainfall $(\mathrm{mm})$ in 2016 and $2001(\mathrm{r}=0.9$, $\mathrm{p}$-value $<0.001$ ) over the 61 conservation units (Pearson correlation coefficient is used); (b) Box plot showing the mRAI results for the 2001 and 2016 total annual rainfall data over a 30 year period.

\section{Appendix B.}

List of the 61 conservation units (CUs) in the Cerrado Biome, designated before 2001 and with a 'strictly protected' status (Table A2).

Table A2. Characteristics of the 61 conservation units (CUs) retained for the landscape change analysis. The data included in this table was extracted from the Brazilian National Register of Conservation Units [37]. The following Portuguese terms are abbreviated: Estação Ecológica (E.E.), Monumento Natural (M.N.), Parque Estadual (P.E.), Parque Nacional (P.N.), Parque Natural Municipal (P.N.M.), Reserva Biológica (R.B.).

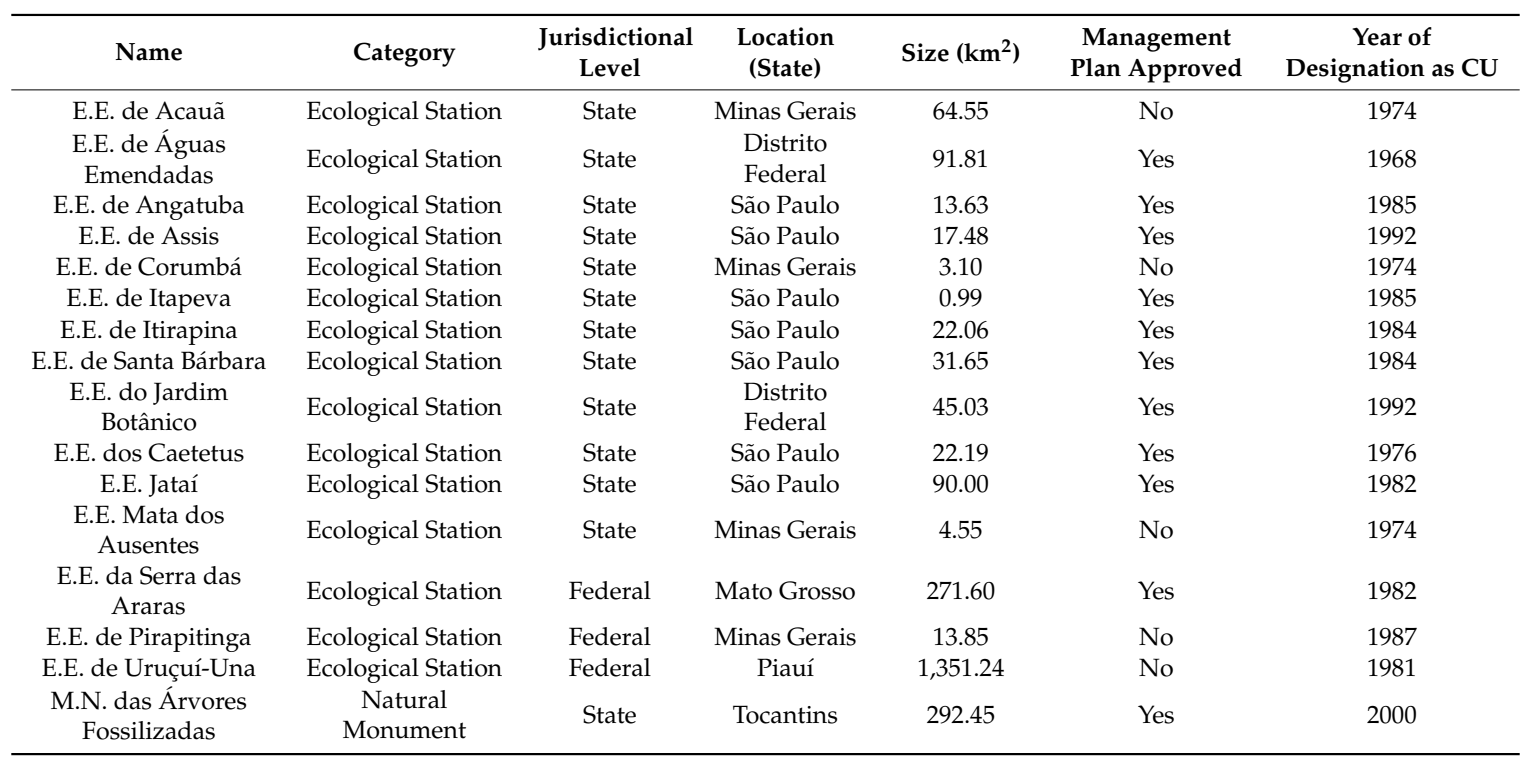


Table A2. Cont.

\begin{tabular}{|c|c|c|c|c|c|c|}
\hline Name & Category & $\begin{array}{c}\text { Jurisdictional } \\
\text { Level }\end{array}$ & $\begin{array}{l}\text { Location } \\
\text { (State) }\end{array}$ & Size $\left(\mathrm{km}^{2}\right)$ & $\begin{array}{c}\text { Management } \\
\text { Plan Approved }\end{array}$ & $\begin{array}{c}\text { Year of } \\
\text { Designation as CU }\end{array}$ \\
\hline $\begin{array}{l}\text { M.N. Estadual Gruta } \\
\text { Rei do Mato }\end{array}$ & $\begin{array}{c}\text { Natural } \\
\text { Monument }\end{array}$ & State & Minas Gerais & 1.41 & Yes & 1984 \\
\hline $\begin{array}{l}\text { P.E. Altamiro de } \\
\text { Moura Pacheco }\end{array}$ & Park & State & Goiás & 31.39 & Yes & 1992 \\
\hline P.E. Biribiri & Park & State & Minas Gerais & 170.03 & Yes & 1998 \\
\hline $\begin{array}{l}\text { P.E. da Serra de } \\
\text { Caldas Novas }\end{array}$ & Park & State & Goiás & 121.59 & Yes & 1970 \\
\hline $\begin{array}{c}\text { P.E. das Nascentes do } \\
\text { Rio Taquari }\end{array}$ & Park & State & $\begin{array}{c}\text { Mato Grosso; } \\
\text { Mato Grosso } \\
\text { do Sul }\end{array}$ & 305.97 & Yes & 1999 \\
\hline P.E. de Águas Quentes & Park & State & Mato Grosso & 15.07 & No & 1978 \\
\hline P.E. de Mirador & Park & State & Maranhão & 4378.50 & No & 1980 \\
\hline P.E. de Terra Ronca & Park & State & Goiás & 569.82 & No & 1989 \\
\hline P.E. do Cerrado & Park & State & Paraná & 18.30 & Yes & 1992 \\
\hline P.E. do Juquery & Park & State & São Paulo & 19.78 & No & 1993 \\
\hline P.E. do Sumidouro & Park & State & Minas Gerais & 20.06 & Yes & 1980 \\
\hline P.E. dos Pirineus & Park & State & Goiás & 28.38 & No & 1987 \\
\hline P.E. Grão Mogol & Park & State & Minas Gerais & 283.91 & No & 1998 \\
\hline $\begin{array}{c}\text { P.E. Gruta da Lagoa } \\
\text { Azul }\end{array}$ & Park & State & Mato Grosso & 125.13 & Yes & 2000 \\
\hline P.E. Lagoa do Cajueiro & Park & State & Minas Gerais & 207.35 & No & 1998 \\
\hline P.E. Mãe Bonifácia & Park & State & Mato Grosso & 0.77 & No & 2000 \\
\hline $\begin{array}{l}\text { P.E. Massairo } \\
\text { Okamura }\end{array}$ & Park & State & Mato Grosso & 0.53 & Yes & 2000 \\
\hline P.E. Mata Seca & Park & State & Minas Gerais & 153.68 & No & 2000 \\
\hline P.E. Matas do Segredo & Park & State & $\begin{array}{l}\text { Mato Grosso } \\
\text { do Sul }\end{array}$ & 1.77 & Yes & 2000 \\
\hline P.E. Pico do Itambé & Park & State & Minas Gerais & 65.21 & Yes & 1998 \\
\hline P.E. Rio Preto & Park & State & Minas Gerais & 121.85 & Yes & 1994 \\
\hline P.E. Serra Azul & Park & State & Mato Grosso & 110.07 & Yes & 1994 \\
\hline P.E. Serra das Araras & Park & State & Minas Gerais & 135.53 & No & 1998 \\
\hline P.E. Serra Negra & Park & State & Minas Gerais & 131.06 & No & 1998 \\
\hline P.E. Verde Grande & Park & State & $\begin{array}{c}\text { Minas } \\
\text { Gerais; Bahia }\end{array}$ & 255.62 & No & 1998 \\
\hline $\begin{array}{l}\text { P.E. Veredas do } \\
\text { Peruaçu }\end{array}$ & Park & State & Minas Gerais & 312.50 & No & 1994 \\
\hline P.E. Zé Bolo Flô & Park & State & Mato Grosso & 0.52 & No & 2000 \\
\hline $\begin{array}{l}\text { P.N. Cavernas do } \\
\text { Peruaçu }\end{array}$ & Park & Federal & Minas Gerais & 564.48 & No & 1999 \\
\hline $\begin{array}{l}\text { P.N. da Chapada dos } \\
\text { Guimarães }\end{array}$ & Park & Federal & Mato Grosso & 326.47 & Yes & 1989 \\
\hline $\begin{array}{c}\text { P.N. da Chapada dos } \\
\text { Veadeiros }\end{array}$ & Park & Federal & Goiás & $2,405.84$ & Yes & 1961 \\
\hline $\begin{array}{l}\text { P.N. da Serra da } \\
\text { Bodoquena }\end{array}$ & Park & Federal & $\begin{array}{l}\text { Mato Grosso } \\
\text { do Sul }\end{array}$ & 769.76 & Yes & 2000 \\
\hline $\begin{array}{c}\text { P.N. da Serra da } \\
\text { Canastra }\end{array}$ & Park & Federal & Minas Gerais & $1,979.71$ & Yes & 1972 \\
\hline P.N. da Serra do Cipó & Park & Federal & $\begin{array}{l}\text { Minas Gerais } \\
\text { Goiás; Mato }\end{array}$ & 316.39 & Yes & 1984 \\
\hline P.N. das Emas & Park & Federal & $\begin{array}{l}\text { Grosso do } \\
\text { Sul }\end{array}$ & $1,327.85$ & Yes & 1961 \\
\hline P.N. de Brasília & Park & Federal & $\begin{array}{l}\text { Distrito } \\
\text { Federal; } \\
\text { Goiás }\end{array}$ & 423.56 & No & 1961 \\
\hline P.N. do Araguaia & Park & Federal & $\begin{array}{l}\text { Tocantins; } \\
\text { Mato Grosso }\end{array}$ & $5,555.03$ & Yes & 1959 \\
\hline $\begin{array}{l}\text { P.N. do Pantanal } \\
\text { Matogrossense }\end{array}$ & Park & Federal & $\begin{array}{l}\text { Mato Grosso; } \\
\text { Mato Grosso } \\
\text { do Sul }\end{array}$ & $1,359.23$ & Yes & 1981 \\
\hline $\begin{array}{l}\text { P.N. Grande Sertão } \\
\text { Veredas }\end{array}$ & Park & Federal & $\begin{array}{c}\text { Minas } \\
\text { Gerais; Bahia }\end{array}$ & $2,308.53$ & Yes & 1989 \\
\hline $\begin{array}{l}\text { P.N.M. Salão de } \\
\text { Pedras }\end{array}$ & Park & Municipal & Minas Gerais & 8.58 & Yes & 1999 \\
\hline R.B. Culuene & Biological Reserve & State & Mato Grosso & 36.14 & No & 1989 \\
\hline R.B. do Cerradão & Biological Reserve & State & $\begin{array}{l}\text { Distrito } \\
\text { Federal }\end{array}$ & 0.54 & No & 1998 \\
\hline R.B. do Gama & Biological Reserve & State & $\begin{array}{l}\text { Distrito } \\
\text { Federal }\end{array}$ & 5.37 & Yes & 1988 \\
\hline R.B. do Guará & Biological Reserve & State & $\begin{array}{l}\text { Distrito } \\
\text { Federal }\end{array}$ & 1.45 & Yes & 1988 \\
\hline R.B. Jaíba & Biological Reserve & State & Minas Gerais & 63.51 & No & 1973 \\
\hline R.B. Serra Azul & Biological Reserve & State & Minas Gerais & 38.43 & No & 1998 \\
\hline
\end{tabular}




\section{Appendix C.}

Table A3. Acquisition details of the selected Landsat scenes (the areas affected by cloudiness are located outside the limits of the studied areas.).

\begin{tabular}{|c|c|c|c|c|c|}
\hline & $\begin{array}{c}\text { Landsat } \\
\text { Mission/Sensor }\end{array}$ & $\begin{array}{l}\text { Acquisition } \\
\text { Date }\end{array}$ & $\begin{array}{c}\text { Solar Zenith } \\
\text { Angle }\left({ }^{\circ}\right)\end{array}$ & $\begin{array}{c}\text { Solar Azimuth } \\
\left.{ }^{\circ}{ }^{\circ}\right)\end{array}$ & $\begin{array}{l}\text { Scene Cloud } \\
\text { Cover }(\%)\end{array}$ \\
\hline \multirow[t]{3}{*}{$217 / 72$} & L5/TM & 01/08/2001 & 50.01 & 46.95 & 34.0 \\
\hline & L7/ETM+ & $10 / 09 / 2001$ & 38.26 & 57.50 & 0.0 \\
\hline & L8/OLI & $10 / 08 / 2016$ & 44.59 & 44.64 & 0.0 \\
\hline \multirow[t]{2}{*}{$217 / 73$} & L7/ETM+ & 10/09/2001 & 39.23 & 56.21 & 10.0 \\
\hline & L8/OLI & $10 / 08 / 2016$ & 45.78 & 43.87 & 0.0 \\
\hline \multirow[t]{2}{*}{$218 / 70$} & L7/ETM+ & 15/07/2001 & 48.52 & 42.92 & 2.0 \\
\hline & L8/OLI & $16 / 07 / 2016$ & 46.63 & 40.70 & 0.0 \\
\hline \multirow[t]{4}{*}{$218 / 71$} & L5/TM & 09/09/2001 & 39.35 & 60.33 & 0.0 \\
\hline & L7/ETM+ & $15 / 07 / 2001$ & 49.73 & 42.27 & 18.0 \\
\hline & L8/OLI & $16 / 07 / 2016$ & 47.87 & 40.05 & 0.0 \\
\hline & L8/OLI & $17 / 08 / 2016$ & 41.68 & 47.44 & 2.2 \\
\hline \multirow[t]{3}{*}{$218 / 72$} & L5/TM & 09/09/2001 & 40.47 & 59.03 & 0.0 \\
\hline & L8/OLI & $17 / 08 / 2016$ & 42.82 & 46.51 & 6.2 \\
\hline & L8/OLI & $18 / 09 / 2016$ & 33.37 & 58.23 & 1.7 \\
\hline \multirow[t]{5}{*}{$218 / 73$} & L5/TM & 09/09/2001 & 41.20 & 57.81 & 0.0 \\
\hline & L7/ETM+ & $15 / 07 / 2001$ & 52.17 & 41.11 & 15.0 \\
\hline & L8/OLI & $16 / 07 / 2016$ & 50.37 & 38.88 & 0.0 \\
\hline & L8/OLI & $17 / 08 / 2016$ & 43.98 & 45.64 & 3.3 \\
\hline & L8/OLI & 18/09/2016 & 34.34 & 56.66 & 2.3 \\
\hline \multirow[t]{3}{*}{$218 / 74$} & L5/TM & 25/09/2001 & 37.45 & 63.23 & 26.0 \\
\hline & L7/ETM+ & $15 / 07 / 2001$ & 53.40 & 40.59 & 7.0 \\
\hline & L8/OLI & 18/09/2016 & 35.33 & 55.20 & 0.0 \\
\hline \multirow[t]{2}{*}{ 219/70 } & L5/TM & $14 / 07 / 2001$ & 50.11 & 44.68 & 0.0 \\
\hline & L8/OLI & 07/07/2016 & 47.40 & 39.29 & 0.0 \\
\hline \multirow[t]{3}{*}{$219 / 71$} & L5/TM & 14/07/2001 & 51.29 & 44.03 & 0.0 \\
\hline & L7/ETM+ & $17 / 04 / 2001$ & 41.03 & 51.75 & 0.0 \\
\hline & L8/OLI & $18 / 04 / 2016$ & 39.52 & 48.72 & 0.1 \\
\hline \multirow[t]{2}{*}{ 219/73 } & L7/ETM+ & 08/09/2001 & 39.83 & 55.44 & 0.0 \\
\hline & L8/OLI & 09/09/2016 & 37.14 & 52.96 & 0.0 \\
\hline \multirow[t]{4}{*}{$219 / 74$} & L7/ETM+ & 06/07/2001 & 54.11 & 39.35 & 0.0 \\
\hline & L7/ETM+ & $07 / 08 / 2001$ & 49.61 & 45.04 & 0.0 \\
\hline & L8/OLI & 07/07/2016 & 52.48 & 37.14 & 0.4 \\
\hline & L8/OLI & 08/08/2016 & 47.46 & 42.70 & 0.0 \\
\hline \multirow[t]{2}{*}{$219 / 76$} & L7/ETM+ & 03/05/2001 & 50.03 & 41.94 & 0.0 \\
\hline & L8/OLI & $04 / 05 / 2016$ & 48.89 & 39.23 & 12.4 \\
\hline \multirow[t]{2}{*}{$220 / 64$} & L5/TM & $19 / 06 / 2001$ & 43.52 & 46.62 & 1.0 \\
\hline & L8/OLI & $28 / 06 / 2016$ & 40.29 & 42.89 & 0.2 \\
\hline \multirow[t]{2}{*}{$220 / 65$} & L5/TM & $19 / 06 / 2001$ & 44.67 & 45.71 & 0.0 \\
\hline & L8/OLI & $28 / 06 / 2016$ & 41.50 & 41.96 & 0.0 \\
\hline \multirow[t]{2}{*}{$220 / 66$} & L7/ETM+ & $24 / 04 / 2001$ & 37.02 & 54.54 & 0.0 \\
\hline & L8/OLI & $25 / 04 / 2016$ & 35.33 & 51.56 & 0.6 \\
\hline \multirow[t]{2}{*}{$220 / 69$} & L7/ETM+ & $26 / 05 / 2001$ & 45.57 & 41.73 & 0.0 \\
\hline & L8/OLI & $27 / 05 / 2016$ & 44.18 & 39.14 & 0.0 \\
\hline
\end{tabular}


Table A3. Cont.

\begin{tabular}{|c|c|c|c|c|c|}
\hline & $\begin{array}{c}\text { Landsat } \\
\text { Mission/Sensor }\end{array}$ & $\begin{array}{l}\text { Acquisition } \\
\text { Date }\end{array}$ & $\begin{array}{c}\text { Solar Zenith } \\
\text { Angle }\left({ }^{\circ}\right)\end{array}$ & $\begin{array}{c}\text { Solar Azimuth } \\
\left({ }^{\circ}\right)\end{array}$ & $\begin{array}{l}\text { Scene Cloud } \\
\text { Cover }(\%)\end{array}$ \\
\hline \multirow[t]{4}{*}{$220 / 70$} & L7/ETM+ & 08/04/2001 & 38.49 & 57.55 & 0.0 \\
\hline & L7/ETM+ & $26 / 05 / 2001$ & 46.79 & 41.02 & 0.0 \\
\hline & L8/OLI & 09/04/2016 & 36.78 & 54.50 & 9.1 \\
\hline & L8/OLI & 27/05/2016 & 45.44 & 38.45 & 0.0 \\
\hline \multirow[t]{2}{*}{$220 / 71$} & L7/ETM+ & 08/04/2001 & 39.45 & 56.25 & 0.0 \\
\hline & L8/OLI & 09/04/2016 & 37.80 & 53.19 & 0.0 \\
\hline \multirow[t]{2}{*}{$220 / 74$} & L5/TM & 06/08/2001 & 51.30 & 46.77 & 0.0 \\
\hline & L8/OLI & $15 / 08 / 2016$ & 45.69 & 44.34 & 9.6 \\
\hline \multirow[t]{4}{*}{$220 / 75$} & L7/ETM+ & 08/04/2001 & 43.56 & 51.84 & 0.0 \\
\hline & L7/ETM+ & $11 / 06 / 2001$ & 54.95 & 37.37 & 0.0 \\
\hline & L8/OLI & $09 / 04 / 2016$ & 42.12 & 48.79 & 0.0 \\
\hline & L8/OLI & $12 / 06 / 2016$ & 53.66 & 35.07 & 3.2 \\
\hline \multirow[t]{2}{*}{$220 / 76$} & L7/ETM+ & $13 / 07 / 2001$ & 56.10 & 39.40 & 6.0 \\
\hline & L8/OLI & $14 / 07 / 2016$ & 54.42 & 37.20 & 12.3 \\
\hline \multirow[t]{2}{*}{$220 / 77$} & L7/ETM+ & $18 / 01 / 2001$ & 33.16 & 90.19 & 35.0 \\
\hline & L8/OLI & 20/01/2016 & 31.09 & 88.64 & 25.9 \\
\hline \multirow[t]{2}{*}{$221 / 64$} & L5/TM & $12 / 07 / 2001$ & 43.40 & 49.25 & 33.0 \\
\hline & L8/OLI & $19 / 06 / 2016$ & 40.11 & 42.22 & 22.4 \\
\hline \multirow[t]{2}{*}{$221 / 65$} & L5/TM & $26 / 06 / 2001$ & 44.89 & 46.12 & 0.0 \\
\hline & L8/OLI & $19 / 06 / 2016$ & 41.33 & 41.31 & 0.2 \\
\hline \multirow[t]{2}{*}{$221 / 69$} & L7/ETM+ & 02/06/2001 & 46.49 & 40.97 & 13.0 \\
\hline & L8/OLI & 03/06/2016 & 45.07 & 38.47 & 2.4 \\
\hline \multirow[t]{2}{*}{$221 / 70$} & L7/ETM+ & 02/06/2001 & 47.72 & 40.30 & 0.0 \\
\hline & L8/OLI & 03/06/2016 & 46.34 & 37.81 & 0.1 \\
\hline \multirow[t]{2}{*}{$221 / 71$} & L7/ETM+ & 21/08/2001 & 42.82 & 51.31 & 0.0 \\
\hline & L8/OLI & $22 / 08 / 2016$ & 40.33 & 48.98 & 1.6 \\
\hline \multirow[t]{2}{*}{$221 / 72$} & L7/ETM+ & 20/07/2001 & 50.38 & 42.53 & 0.0 \\
\hline & L8/OLI & $21 / 07 / 2016$ & 48.46 & 40.31 & 0.0 \\
\hline \multirow[t]{4}{*}{$221 / 76$} & L7/ETM+ & $15 / 04 / 2001$ & 46.14 & 47.95 & 0.0 \\
\hline & L7/ETM+ & 05/08/2001 & 52.42 & 43.40 & 20.0 \\
\hline & L8/OLI & $16 / 04 / 2016$ & 44.84 & 44.97 & 0.0 \\
\hline & L8/OLI & 06/08/2016 & 50.38 & 41.07 & 0.0 \\
\hline \multirow[t]{2}{*}{$221 / 77$} & L7/ETM+ & $15 / 04 / 2001$ & 47.28 & 47.19 & 12.0 \\
\hline & L8/OLI & $16 / 04 / 2016$ & 46.02 & 44.23 & 0.7 \\
\hline \multirow[t]{2}{*}{$222 / 65$} & L7/ETM+ & $27 / 07 / 2001$ & 41.35 & 49.92 & 0.0 \\
\hline & L8/OLI & 28/07/2016 & 39.07 & 47.81 & 0.0 \\
\hline \multirow[t]{4}{*}{$222 / 71$} & L7/ETM+ & 06/04/2001 & 39.13 & 57.33 & 0.0 \\
\hline & L7/ETM+ & 27/07/2001 & 48.18 & 44.61 & 0.0 \\
\hline & L8/OLI & $07 / 04 / 2016$ & 47.45 & 54.27 & 0.4 \\
\hline & L8/OLI & 28/07/2016 & 46.11 & 42.36 & 0.0 \\
\hline \multirow[t]{2}{*}{$222 / 76$} & L7/ETM+ & $11 / 07 / 2001$ & 56.28 & 39.14 & 7.0 \\
\hline & L8/OLI & $12 / 07 / 2016$ & 54.63 & 36.93 & 7.5 \\
\hline \multirow[t]{2}{*}{$223 / 67$} & L7/ETM+ & 02/07/2001 & 45.65 & 43.14 & 0.0 \\
\hline & L8/OLI & 03/07/2016 & 43.86 & 40.88 & 0.0 \\
\hline \multirow[t]{2}{*}{$223 / 68$} & L7/ETM+ & 02/07/2001 & 46.85 & 42.37 & 1.0 \\
\hline & L8/OLI & 03/07/2016 & 45.09 & 40.13 & 0.0 \\
\hline
\end{tabular}


Table A3. Cont.

\begin{tabular}{|c|c|c|c|c|c|}
\hline & $\begin{array}{c}\text { Landsat } \\
\text { Mission/Sensor }\end{array}$ & $\begin{array}{l}\text { Acquisition } \\
\text { Date }\end{array}$ & $\begin{array}{l}\text { Solar Zenith } \\
\text { Angle }\left({ }^{\circ}\right)\end{array}$ & $\begin{array}{c}\text { Solar Azimuth } \\
\left({ }^{\circ}\right)\end{array}$ & $\begin{array}{l}\text { Scene Cloud } \\
\text { Cover }(\%)\end{array}$ \\
\hline \multirow[t]{2}{*}{$224 / 71$} & L7/ETM+ & 06/05/2001 & 44.63 & 44.54 & 0.0 \\
\hline & L8/OLI & 07/05/2016 & 43.30 & 41.73 & 0.2 \\
\hline \multirow[t]{2}{*}{$224 / 72$} & L7/ETM+ & 09/07/2001 & 51.44 & 40.75 & 2.0 \\
\hline & L8/OLI & $10 / 07 / 2016$ & 49.70 & 38.53 & 0.0 \\
\hline \multirow[t]{2}{*}{$224 / 73$} & L7/ETM+ & 09/07/2001 & 52.68 & 40.21 & 4.0 \\
\hline & L8/OLI & $10 / 07 / 2016$ & 50.97 & 38.00 & 0.0 \\
\hline \multirow[t]{2}{*}{$225 / 70$} & L7/ETM+ & 27/04/2001 & 41.80 & 48.52 & 0.0 \\
\hline & L8/OLI & $28 / 04 / 2016$ & 40.35 & 45.57 & 19.3 \\
\hline \multirow[t]{2}{*}{$225 / 74$} & L7/ETM+ & 27/04/2001 & 46.39 & 45.05 & 1.0 \\
\hline & L8/OLI & 28/04/2016 & 45.11 & 42.18 & 23.0 \\
\hline \multirow[t]{2}{*}{$226 / 70$} & L7/ETM+ & 08/08/2001 & 44.79 & 48.37 & 0.0 \\
\hline & L8/OLI & 09/08/2016 & 42.48 & 46.11 & 1.4 \\
\hline \multirow[t]{4}{*}{$226 / 71$} & L7/ETM+ & $18 / 04 / 2001$ & 41.23 & 51.29 & 0.0 \\
\hline & L7/ETM+ & 09/09/2001 & 37.58 & 58.43 & 13.0 \\
\hline & L8/OLI & $19 / 04 / 2016$ & 39.72 & 48.26 & 0.0 \\
\hline & L8/OLI & 10/09/2016 & 34.80 & 56.14 & 0.1 \\
\hline \multirow[t]{2}{*}{$226 / 74$} & L7/ETM+ & 07/07/2001 & 54.05 & 39.47 & 0.0 \\
\hline & L8/OLI & 24/07/2016 & 50.49 & 39.70 & 0.0 \\
\hline \multirow[t]{2}{*}{$226 / 75$} & L7/ETM+ & 07/07/2001 & 55.31 & 39.03 & 0.0 \\
\hline & L8/OLI & $24 / 07 / 2016$ & 51.74 & 39.18 & 0.0 \\
\hline \multirow[t]{2}{*}{$227 / 71$} & L7/ETM+ & $12 / 06 / 2001$ & 49.98 & 39.31 & 1.0 \\
\hline & L8/OLI & 13/06/2016 & 48.55 & 36.94 & 0.0 \\
\hline \multirow[t]{2}{*}{$227 / 72$} & L7/ETM+ & $30 / 07 / 2001$ & 48.84 & 44.57 & 0.0 \\
\hline & L8/OLI & $31 / 07 / 2016$ & 46.76 & 42.31 & 0.0 \\
\hline
\end{tabular}




\section{Appendix D.}

Land use and land cover (LULC) transition matrices of the 61 studied conservation units (CUs) (Table A4) and their buffer zones (BZs) (Table A5).

Table A4. LULC transition matrix of the CUs. Entries correspond to the surface area expressed in hectares.

\begin{tabular}{|c|c|c|c|c|c|c|c|c|c|c|c|c|}
\hline \multirow{13}{*}{2001} & \multirow[b]{3}{*}{ Natural Forest } & \multicolumn{10}{|c|}{2016} & \multirow[b]{2}{*}{ Total 2001} \\
\hline & & $\begin{array}{c}\text { Natural } \\
\text { Forest }\end{array}$ & \multirow{2}{*}{$\begin{array}{c}\begin{array}{c}\text { Non Forest } \\
\text { Natural } \\
\text { Formation }\end{array} \\
111,766 \\
\end{array}$} & $\begin{array}{c}\text { Forest } \\
\text { Plantation }\end{array}$ & Pasture & Agriculture & $\begin{array}{l}\text { Mosaic of } \\
\text { Agriculture } \\
\text { and Pasture }\end{array}$ & $\begin{array}{c}\text { Urban } \\
\text { Infrastructure }\end{array}$ & Mining & $\begin{array}{l}\text { Other Non } \\
\text { Vegetated } \\
\text { Area }\end{array}$ & Water & \\
\hline & & $1,263,963$ & & 485 & 11,550 & 5566 & 32 & 3 & 0 & 190 & 1328 & $1,394,883$ \\
\hline & $\begin{array}{c}\text { Non Forest } \\
\text { Natural } \\
\text { Formation }\end{array}$ & 93,609 & $1,020,959$ & 34 & 20,460 & 14,175 & 4 & 26 & 0 & 10,871 & 3428 & $1,163,566$ \\
\hline & $\begin{array}{c}\text { Forest } \\
\text { Plantation }\end{array}$ & 36 & 31 & 1264 & 21 & 5 & 0 & 0 & 0 & 3 & 0 & 1360 \\
\hline & Pasture & 19,188 & 27,695 & 97 & 73,342 & 3834 & 231 & 15 & 0 & 437 & 124 & 124,963 \\
\hline & Agriculture & 350 & 496 & 1 & 387 & 1072 & 0 & 0 & 0 & 14 & 4 & 2324 \\
\hline & $\begin{array}{l}\text { Mosaic of } \\
\text { Agriculture } \\
\text { and Pasture }\end{array}$ & 511 & 6 & 2 & 74 & 1 & 464 & 1 & 0 & 0 & 0 & 1059 \\
\hline & $\begin{array}{c}\text { Urban } \\
\text { Infrastructure }\end{array}$ & 17 & 11 & 0 & 9 & 0 & 5 & 181 & 0 & 3 & 0 & 226 \\
\hline & Mining & 0 & 0 & 0 & 0 & 0 & 0 & 0 & 0 & 0 & 0 & 0 \\
\hline & $\begin{array}{c}\text { Other Non } \\
\text { Vegetated Area }\end{array}$ & 269 & 12,794 & 22 & 1277 & 146 & 0 & 19 & 0 & 16,724 & 24 & 31,275 \\
\hline & Water & 2089 & 4484 & 0 & 78 & 19 & 3 & 0 & 0 & 103 & 28,981 & 35,757 \\
\hline & Total 2016 & $1,380,032$ & $1,178,242$ & 1905 & 107,198 & 24,818 & 739 & 245 & 0 & 28,345 & 33,889 & \\
\hline
\end{tabular}


Table A5. LULC transition matrix of the BZs. Entries correspond to the surface area expressed in hectares.

\begin{tabular}{|c|c|c|c|c|c|c|c|c|c|c|c|c|}
\hline & & \multicolumn{10}{|c|}{2016} & \multirow[b]{2}{*}{ Total 2001} \\
\hline & & $\begin{array}{l}\text { Natural } \\
\text { Forest }\end{array}$ & $\begin{array}{l}\text { Non Forest } \\
\text { Natural } \\
\text { Formation }\end{array}$ & $\begin{array}{c}\text { Forest } \\
\text { Plantation }\end{array}$ & Pasture & Agriculture & $\begin{array}{c}\text { Mosaic of } \\
\text { Agriculture } \\
\text { and Pasture }\end{array}$ & $\begin{array}{c}\text { Urban } \\
\text { Infrastructure }\end{array}$ & Mining & $\begin{array}{l}\text { Other Non } \\
\text { Vegetated } \\
\text { Area }\end{array}$ & Water & \\
\hline \multirow{11}{*}{2001} & Natural Forest & $2,230,019$ & 181,520 & 26,046 & 202,690 & 75,460 & 4843 & 3870 & 68 & 7671 & 4274 & $2,736,461$ \\
\hline & $\begin{array}{l}\text { Non Forest } \\
\text { Natural } \\
\text { Formation }\end{array}$ & 185,568 & 969,975 & 6689 & 98,476 & 64,452 & 234 & 6596 & 27 & 23,953 & 7043 & $1,363,013$ \\
\hline & $\begin{array}{c}\text { Forest } \\
\text { Plantation }\end{array}$ & 1205 & 286 & 77,447 & 304 & 683 & 129 & 38 & 0 & 103 & 21 & 80,216 \\
\hline & Pasture & 167,162 & 82,764 & 22,916 & 968,606 & 180,682 & 22,251 & 14,219 & 70 & 6246 & 1310 & $1,466,226$ \\
\hline & Agriculture & 4899 & 2387 & 1479 & 18,253 & 293,811 & 373 & 308 & 1 & 439 & 237 & 322,187 \\
\hline & $\begin{array}{l}\text { Mosaic of } \\
\text { Agriculture } \\
\text { and Pasture }\end{array}$ & 7623 & 133 & 2118 & 11,809 & 2960 & 30,248 & 874 & 6 & 40 & 53 & 55,864 \\
\hline & $\begin{array}{c}\text { Urban } \\
\text { Infrastructure }\end{array}$ & 828 & 1605 & 11 & 1660 & 126 & 307 & 79,400 & 41 & 697 & 53 & 84,728 \\
\hline & Mining & 7 & 7 & 1 & 28 & 2 & 1 & 161 & 110 & 62 & 7 & 386 \\
\hline & $\begin{array}{c}\text { Other Non } \\
\text { Vegetated Area }\end{array}$ & 2758 & 22,268 & 569 & 10,856 & 7075 & 32 & 3842 & 70 & 41,411 & 1751 & 90,632 \\
\hline & Water & 3534 & 6526 & 188 & 797 & 388 & 81 & 54 & 17 & 2385 & 89,219 & 103,189 \\
\hline & Total 2016 & $2,603,603$ & $1,267,471$ & 137,464 & $1,313,479$ & 625,639 & 58,499 & 109,362 & 410 & 83,007 & 103,968 & \\
\hline
\end{tabular}




\section{Appendix E.}

Results of the three landscape metrics' values for the 'Non-Forest Natural Formation' (Figure A2), 'Pasture' (Figure A3), and 'Agriculture' (Figure A4) vegetation cover types for the whole study area (CUs and BZs, separately) and per Brazilian state (CUs and BZs combined).
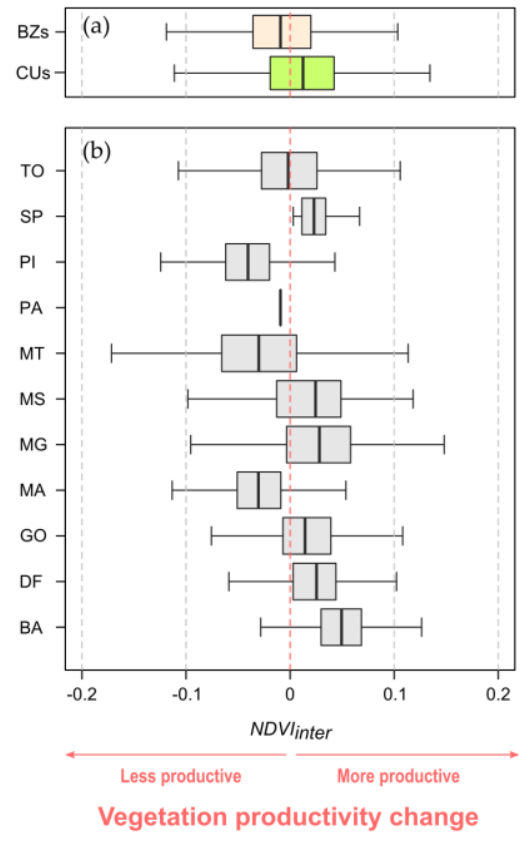

Non-Forest Natural Formation
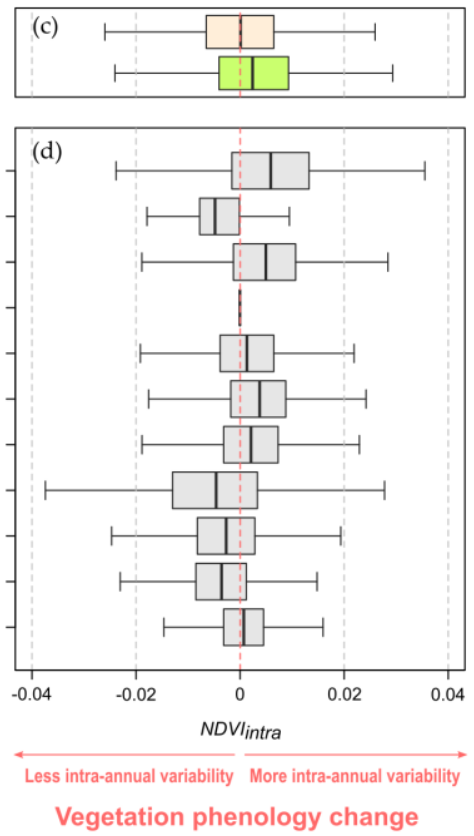
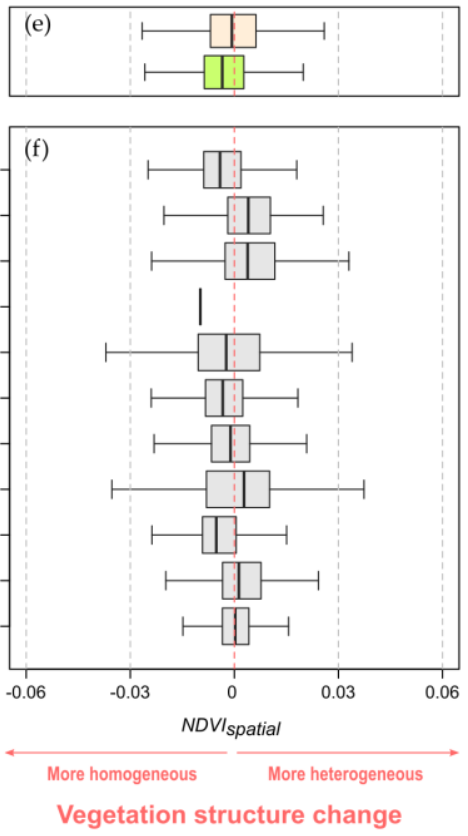

Figure A2. Boxplots of the landscape metrics' values of the cells belonging to the 'Non-Forest Natural Formation' category: (a) $N D V I_{\text {inter }}$ in the buffer zones (BZs) and conservation units (CUs); (b) $N D V I_{\text {inter }}$ in each state; (c) $N D V I_{\text {intra }}$ in the BZs and CUs; (d) $N D V I_{\text {intra }}$ in each state; (e) $N D V I_{\text {spatial }}$ in the BZs and CUs; (f) $N D V I_{\text {spatial }}$ in each state. Number of $250 \mathrm{~m}$ resolution (6.25 ha) cells located inside the 61 conservation units $=77,430$ and in their buffer zones $=42,286$. Number of cells in each Brazilian state with n > 0: Tocantins (TO, 47,905), São Paulo (SP, 39), Piauí (PI, 2302), Pará (PA, 1), Mato Grosso (MT, 7910), Mato Grosso do Sul (MS, 1198), Minas Gerais (MG, 11,902), Maranhão (MA, 13,653), Goiás (GO, 20,502), Distrito Federal (DF, 1691), Bahia (BA, 12,613).

The non-forest natural formations experienced divergent dynamics in the BZs and CUs in terms of productivity change, as shown by the opposed distribution of their $N D V I_{\text {inter }}$ values (Figure A2a). In the BZs, $58.9 \%$ of the grassland and wetland areas were characterized by a decrease in the annual average of NDVI, whereas in the CUs, $60.4 \%$ of these areas experienced an increase in NDVI. However, in Figure A2b, we can observe a clear disparity of trends depending on the location of these areas. For example, the near totality $(90.5 \%)$ of this vegetation type in Piauí has experienced a decrease in productivity, while the opposite trend can be observed in Bahia, where the non-forest natural vegetation productivity has increased in $92.8 \%$ of the sampled cells.

Similarly, the results for the $N D V I_{\text {intra }}$ metric were diverse according to the location of the non-forest natural formation areas (Figure A2d). Hence, at the Cerrado level, these areas did not present a clear trend inside the BZs and slightly tended to an increase in the intra-annual variability of NDVI in the CUs (59.9\% of the analyzed cells in the CUs followed this trend) (Figure A2c). 
The non-forest natural vegetation obtained similar results to the natural forest areas for the $N D V I_{\text {spatial }}$ metric (Figure A2e), suggesting a general homogenization of its surface. This trend is representative of a larger proportion of surface area in the CUs $(65.3 \%)$ than in the BZs $(53.1 \%)$. However, the magnitude of change is relatively low (Figure A2e; Figure A2f).
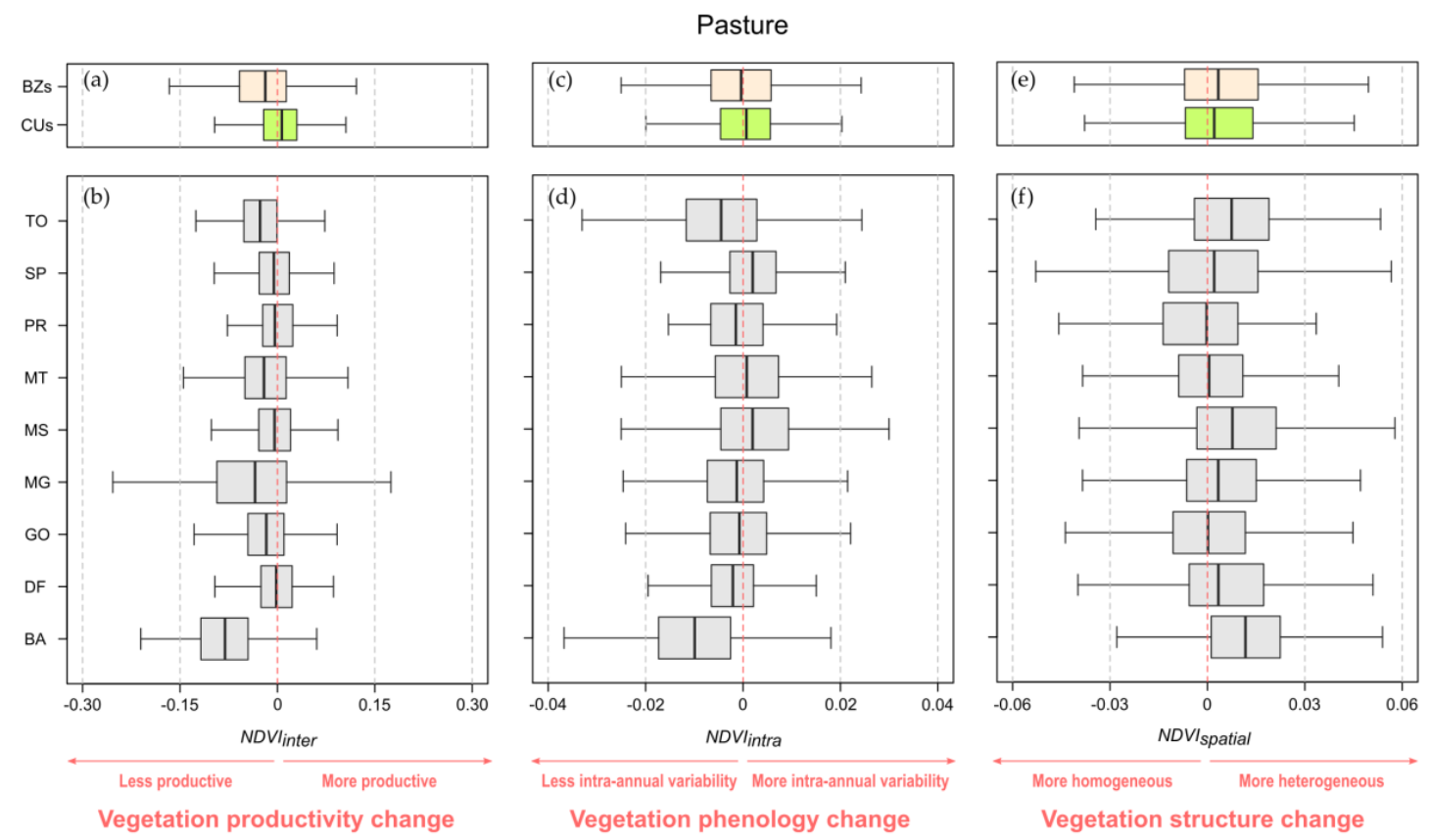

Figure A3. Boxplots of the landscape metrics' values of the cells belonging to the 'Pasture' category: (a) NDVI $I_{\text {inter }}$ in the buffer zones (BZs) and conservation units (CUs); (b) NDVI inter in each state; (c) $N D V I_{\text {intra }}$ in the BZs and CUs; (d) NDVI intra in each state; (e) $N D V I_{\text {spatial }}$ in the BZs and CUs; (f) $N D V I_{\text {spatial }}$ in each state. Number of $250 \mathrm{~m}$ resolution (6.25 ha) cells located inside the 61 conservation units $=1319$ and in their buffer zones $=34,832$. Number of cells in each Brazilian state with $\mathrm{n}>0$ : Tocantins (TO, 436), São Paulo (SP, 3147), Paraná (PR, 45), Mato Grosso (MT, 5488), Mato Grosso do Sul (MS, 6666), Minas Gerais (MG, 13,444), Goiás (GO, 5233), Distrito Federal (DF, 673), Bahia (BA, 1019).

Pastures in the BZs generally experienced a loss in productivity $(64.8 \%$ of the analyzed cells in the BZs experienced a decrease in the annual average of NDVI) (Figure A3a), the most affected areas being located in the state of Bahia (where $93 \%$ of the pasture cells have a negative $N D V I_{\text {inter }}$ value) (Figure A3b). In the CUs, the number of pasture cells analyzed was limited to 1319 cells (approximately $8244 \mathrm{ha}), 57.2 \%$ of which have experienced a gain in the annual average of NDVI.

Regarding the intra-annual variability of the pastures (as measured by the NDVI intra, presented in Figure A3c), no clear trend is noticeable except locally, in the CUs and BZs of Bahia, where the intra-annual variability of NDVI decreased in $82.3 \%$ of the analyzed pastureland (Figure A3d).

The spatial variability of NDVI in pastures did not follow any clear trend (Figure A3e). A slight trend towards a general increase in the spatial variability of NDVI is noted within the pasture areas in the BZs (Figure A3e), which is influenced by the dynamic of the pastures in the states of Bahia, Tocantins, and Mato Grosso do Sul (Figure A3f). 

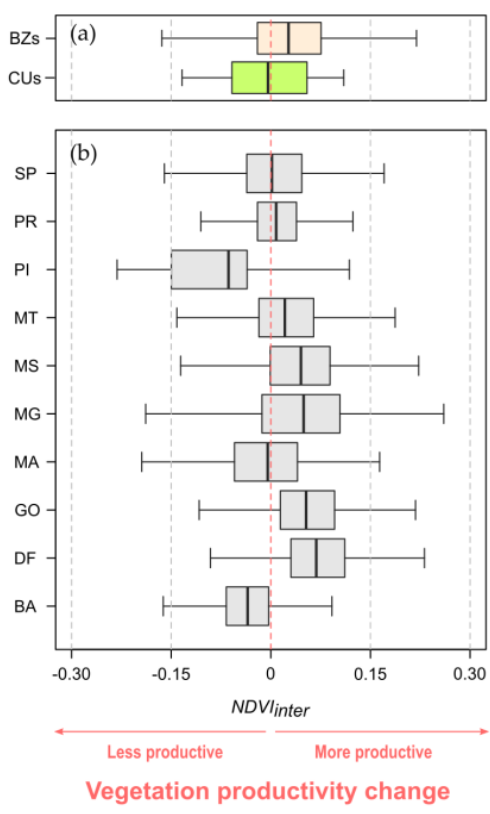
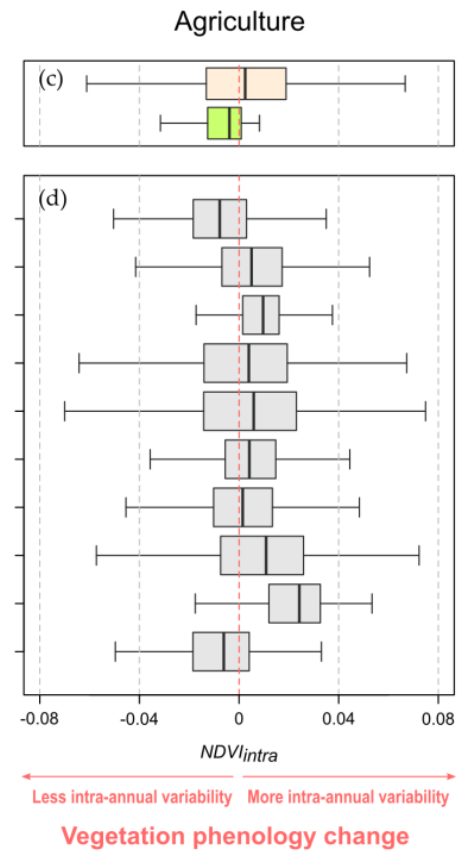
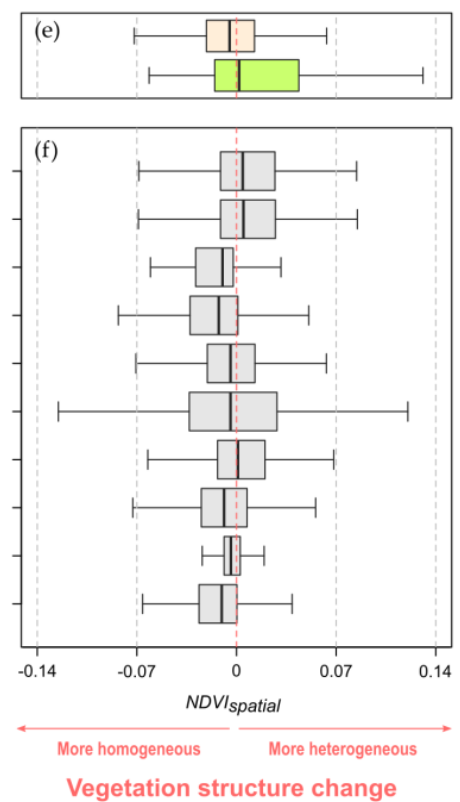

Figure A4. Boxplots of the landscape metrics' values of the cells belonging to the 'Agriculture' category: (a) $N D V I_{\text {inter }}$ in the buffer zones (BZs) and conservation units (CUs); (b) NDVI inter in each state; (c) $N D V I_{\text {intra }}$ in the BZs and CUs; (d) NDVI intra in each state; (e) NDVI spatial in the BZs and CUs; (f) $N D V I_{\text {spatial }}$ in each state. Number of $250 \mathrm{~m}$ resolution $(6.25 \mathrm{ha})$ cells located inside the 61 conservation units $=41$ and in their buffer zones $=31,246$. Number of cells in each Brazilian state with $n>0$ : São Paulo (SP, 5161), Paraná (PR, 913), Piauí (PI, 153), Mato Grosso (MT, 2394), Mato Grosso do Sul (MS, 8489), Minas Gerais (MG, 1282), Maranhão (MA, 2202), Goiás (GO, 7464), Distrito Federal (DF, 627), Bahia (BA, 2602).

The results of the monitored agricultural areas in the BZs (Figure A4a) show a general trend of productivity increase (64.6\% of the analyzed Agriculture cells in the BZs experienced an increase in the annual average of NDVI, thus a positive $N D V I_{\text {inter }}$ value). This trend is especially clear in the states of Goiás and Distrito Federal, where the proportion of agricultural areas with an increased productivity accounted for $82.4 \%$ and $84.7 \%$, respectively (Figure A4b).

However, the agricultural land in the BZs showed the highest dispersion of $N D V I_{\text {inter }}$ values (Figure A4a) of all the four vegetation types, reflecting the rich diversity of cropping systems. This variability in the $N D V I_{\text {inter }}$ results is illustrated by the different trends followed by the agricultural land in the different states, and by the high dispersion of values within each state (Figure A4b). The few agricultural areas monitored within the CUs' limits (41 cells or 256 ha) did not show a clear trend (Figure A4a).

Just as for $N D V I_{\text {inter, }}$, the agricultural land in the BZs exhibited the highest dispersion of $N D V I_{\text {intra }}$ values of all vegetation types (Figure A4c). However, in this case, the high diversity of results at the state level (Figure A4d), resulted in a lack of a common trend at the biome level. Nevertheless, the agricultural land of the study areas in Distrito Federal and Piauí, exhibited a clear, increased intra-annual variability of NDVI trend (accounting for $88.5 \%$ and $79.7 \%$ of their total agricultural area, respectively), even if the sampled surface area was relatively small for both states ( 3918 ha for Distrito Federal and 956.25 ha for Piauí). Conversely, most of the limited sample of agricultural land inside the CUs (73.2\%) experienced a decrease in the intra-annual variability of NDVI (Figure A4c).

As for the other landscape metrics, the agricultural land in the BZs exhibited a greater dispersion of the $N D V I_{\text {spatial }}$ values than the rest of vegetation cover types (Figure A4e), and, in this case, a slight trend towards a general homogenization of the agricultural landscapes is observed. This trend represented $58.7 \%$ of the monitored agricultural land in the BZs and was representative of the general 
changes observed in the Piauí, Bahia, and Mato Grosso states (Figure A4f). The few agricultural areas in the CUs seemed to have become slightly more heterogeneous.

The dispersion of the $N D V I_{\text {spatial }}$ values varies considerably from one state to another (Figure A4f), Minas Gerais being the state with the most contrasted agricultural landscape in terms of magnitude of vegetation structure change, and in contrast, the agricultural land in the Distrito Federal has experienced contrasted changes but all of limited magnitude.

\section{References}

1. UNEP-WCMC; IUCN. Protected Planet Report 2016; UNEP-WCMC and IUCN: Cambridge, UK; Gland, Switzerland, 2016; ISBN 978-92-807-3587-1.

2. Hansen, A.J.; DeFries, R. Ecological Mechanisms Linking Protected Areas. Ecol. Appl. 2007, 17, 974-988. [CrossRef]

3. DeFries, R.; Karanth, K.K.; Pareeth, S. Interactions between protected areas and their surroundings in human-dominated tropical landscapes. Biol. Conserv. 2010, 143, 2870-2880. [CrossRef]

4. Ndegwa Mundia, C.; Murayama, Y. Analysis of land use/cover changes and animal population dynamics in a wildlife sanctuary in East Africa. Remote Sens. 2009, 1, 952-970. [CrossRef]

5. Spear, S.F.; Storfer, A. Landscape genetic structure of coastal tailed frogs (Ascaphus truei) in protected vs. managed forests. Mol. Ecol. 2008, 17, 4642-4656. [CrossRef] [PubMed]

6. IPBES. Summary for Policymakers of the Global Assessment Report on Biodiversity and Ecosystem Services of the Intergovernmental Science-Policy Platform on Biodiversity and Ecosystem Services; Díaz, S., Settele, J., Brondízio, E.S., Ngo, H.T., Guèze, M., Agard, J., Arneth, A., Balvanera, P., Brauman, K.A., Butchart, S.H.M., et al., Eds.; IPBES Secretariat: Bonn, Germany, 2019; 56p. [CrossRef]

7. Blanco, J.; Bellón, B.; Fabricius, C.; Roque, F.O.; Pays, O.; Laurent, F.; Fritz, H.; Renaud, P. Interface processes between protected and unprotected areas: A global review and ways forward. Glob. Chang. Biol. 2020, 26, 1138-1154. [CrossRef]

8. Scharsich, V.; Mtata, K.; Hauhs, M.; Lange, H.; Bogner, C. Analysing land cover and land use change in the Matobo National Park and surroundings in Zimbabwe. Remote Sens. Environ. 2017, 194, 278-286. [CrossRef]

9. Kintz, D.B.; Young, K.R.; Crews-Meyer, K.A. Implications of land use/land cover change in the buffer zone of a national park in the tropical Andes. Environ. Manag. 2006, 38, 238-252. [CrossRef]

10. Wang, Y.; Mitchell, B.R.; Nugranad-Marzilli, J.; Bonynge, G.; Zhou, Y.; Shriver, G. Remote sensing of land-cover change and landscape context of the National Parks: A case study of the Northeast Temperate Network. Remote Sens. Environ. 2009, 113, 1453-1461. [CrossRef]

11. De Moraes, M.C.P.; de Mello, K.; Toppa, R.H. Protected areas and agricultural expansion: Biodiversity conservation versus economic growth in the Southeast of Brazil. J. Environ. Manag. 2017, 188, 73-84. [CrossRef] [PubMed]

12. Jones, D.A.; Hansen, A.J.; Bly, K.; Doherty, K.; Verschuyl, J.P.; Paugh, J.I.; Carle, R.; Story, S.J. Monitoring land use and cover around parks: A conceptual approach. Remote Sens. Environ. 2009, 113, 1346-1356. [CrossRef]

13. Szantoi, Z.; Brink, A.; Buchanan, G.; Bastin, L.; Lupi, A.; Simonetti, D.; Mayaux, P.; Peedell, S.; Davy, J. A simple remote sensing based information system for monitoring sites of conservation importance. Remote Sens. Ecol. Conserv. 2016, 2, 16-24. [CrossRef]

14. Mehring, M.; Stoll-Kleemann, S. How effective is the buffer zone? linking institutional processes with satellite images from a case study in the Lore Lindu forest biosphere reserve, Indonesia. Ecol. Soc. 2011, 16, 16. [CrossRef]

15. Sánchez-Azofeifa, G.A.; Daily, G.C.; Pfaff, A.S.P.; Busch, C. Integrity and isolation of Costa Rica's national parks and biological reserves: Examining the dynamics of land-cover change. Biol. Conserv. 2003, 109, 123-135. [CrossRef]

16. Tang, L.; Shao, G.; Piao, Z.; Dai, L.; Jenkins, M.A.; Wang, S.; Wu, G.; Wu, J.; Zhao, J. Forest degradation deepens around and within protected areas in East Asia. Biol. Conserv. 2010, 143, 1295-1298. [CrossRef]

17. Nagendra, H.; Tucker, C.; Carlson, L.; Southworth, J.; Karmacharya, M.; Karna, B. Monitoring parks through remote sensing: Studies in Nepal and Honduras. Environ. Manag. 2004, 34, 748-760. [CrossRef] [PubMed]

18. Tang, J.; Körner, C.; Muraoka, H.; Piao, S.; Shen, M.; Thackeray, S.J.; Yang, X. Emerging opportunities and challenges in phenology: A review. Ecosphere 2016, 7, e01436. [CrossRef] 
19. Flores, L.M.A.; Zanette, L.R.S.; Araujo, F.S. Effects of habitat simplification on assemblages of cavity nesting bees and wasps in a semiarid neotropical conservation area. Biodivers. Conserv. 2018, 27, 311-328. [CrossRef]

20. Šímová, I.; Storch, D. The enigma of terrestrial primary productivity: Measurements, models, scales and the diversity-productivity relationship. Ecography 2017, 40, 239-252. [CrossRef]

21. Bégué, A.; Arvor, D.; Bellón, B.; Betbeder, J.; de Abelleyra, D.; Ferraz, R.P.D.; Lebourgeois, V.; Lelong, C.; Simões, M.; Verón, S.R. Remote Sensing and Cropping Practices: A Review. Remote Sens. 2018, 10, 99. [CrossRef]

22. Koltunov, A.; Ustin, S.L.; Asner, G.P.; Fung, I. Selective logging changes forest phenology in the Brazilian Amazon: Evidence from MODIS image time series analysis. Remote Sens. Environ. 2009, 113, 2431-2440. [CrossRef]

23. Liao, C.; Clark, P.E.; DeGloria, S.D. Bush encroachment dynamics and rangeland management implications in southern Ethiopia. Ecol. Evol. 2018, 8, 11694-11703. [CrossRef]

24. Wang, J.; Rich, P.M.; Price, K.P. Temporal responses of NDVI to precipitation and temperature in the central Great Plains, USA. Int. J. Remote Sens. 2003, 24, 2345-2364. [CrossRef]

25. Zhang, Y.; Hu, Z.; Qi, W.; Wu, X.; Bai, W.; Li, L.; Ding, M.; Liu, L.; Wang, Z.; Zheng, D. Assessment of effectiveness of nature reserves on the Tibetan Plateau based on net primary production and the large sample comparison method. J. Geogr. Sci. 2016, 26, 27-44. [CrossRef]

26. Hartter, J.; Ryan, S.J.; Southworth, J.; Chapman, C.A. Landscapes as continuous entities: Forest disturbance and recovery in the Albertine Rift landscape. Landsc. Ecol. 2011, 26, 877. [CrossRef]

27. Alcaraz-Segura, D.; Cabello, J.; Paruelo, J.M.; Delibes, M. Trends in the surface vegetation dynamics of the National Parks of Spain as observed by satellite sensors. Appl. Veg. Sci. 2008, 11, 431-440. [CrossRef]

28. Klink, C.A.; Machado, R.B. Conservation of the Brazilian Cerrado. Conserv. Biol. 2005, 19, 707-713. [CrossRef]

29. Rausch, L.L.; Gibbs, H.K.; Schelly, I.; Brandão Jr, A.; Morton, D.C.; Filho, A.C.; Strassburg, B.; Walker, N.; Noojipady, P.; Barreto, P.; et al. Soy expansion in Brazil's Cerrado. Conserv. Lett. 2019, 12, 12. [CrossRef]

30. Strassburg, B.B.N.; Brooks, T.; Feltran-Barbieri, R.; Iribarrem, A.; Crouzeilles, R.; Loyola, R.; Latawiec, A.E.; Oliveira Filho, F.J.B.; Scaramuzza, C.A.d.M.; Scarano, F.R.; et al. Moment of truth for the Cerrado hotspot. Nat. Ecol. Evol. 2017, 1, 99. [CrossRef]

31. Sano, E.E.; Rosa, R.; Scaramuzza, C.A.d.M.; Adami, M.; Bolfe, E.L.; Coutinho, A.C.; Esquerdo, J.C.D.M.; Maurano, L.E.P.; Narvaes, I.d.S.; de Oliveira Filho, F.J.B.; et al. Land use dynamics in the Brazilian Cerrado in the period from 2002 to 2013. Pesqui. Agropecuária Bras. 2019, 54. [CrossRef]

32. De Oliveira, G.B. O Novo Código Florestal e a Reserva Legal do CERRADO; Universidade de Brasília: Brasília, Distrito Federal, Brazil, 2015; 141p. [CrossRef]

33. Carranza, T.; Balmford, A.; Kapos, V.; Manica, A. Protected area effectiveness in reducing conversion in a rapidly vanishing ecosystem: The Brazilian Cerrado. Conserv. Lett. 2014, 7, 216-223. [CrossRef]

34. Françoso, R.D.; Brandão, R.; Nogueira, C.C.; Salmona, Y.B.; Machado, R.B.; Colli, G.R. Habitat loss and the effectiveness of protected areas in the Cerrado Biodiversity Hotspot. Nat. Conserv. 2015, 13, 35-40. [CrossRef]

35. Silva, M. The Brazilian protected areas program. Conserv. Biol. 2005, 19, 608-611. [CrossRef]

36. MMA. Cadastro Nacional de Unidades de Conservação. Ministério do Meio Ambiente. Available online: https://www.mma.gov.br/areas-protegidas/cadastro-nacional-de-ucs (accessed on 15 October 2019).

37. MMA. Unidades de Conservação do Brasil (Atualização continua). Ministério do Meio Ambiente. Available online: mapas.mma.gov.br/i3geo/datadownload.htm (accessed on 10 October 2019).

38. MMA/DSG. Base Cartográfica do Estado de Mato Grosso na escala 1.100.000. Ministério do Meio Ambiente, Divisão do Serviço Geográfico do Exército Brasileiro. Available online: http://www.seplan.mt.gov.br/-/ 10951338-bases-cartograficas (accessed on 16 October 2019).

39. Embrapa Informática Agropecuária. Unidades de Conservação de Proteção Integral. SIAGEO Amazônia. Available online: https:/www.amazonia.cnptia.embrapa.br/geonetwork/srv/por/metadata.show?id=87\& currTab=simple (accessed on 16 October 2019).

40. IAP. Plano de Manejo: Parque Estadual do Cerrado; Instituto Ambiental do Paraná: Curitiba, Paraná, Brazil, 2002; 179p. Available online: http://www.iap.pr.gov.br/pagina-1212.html (accessed on 20 October 2019).

41. Brazil. Lei no 9.985, de 18 de Julho de 2000; Diário Oficial da União: Brasília, Brazil, 2000.

42. Brazil. Conselho Nacional do Meio Ambiente. Resolução CONAMA no. 13, de 06 de Dezembro de 1990; Diário Oficial da União: Brasília, Brazil, 1990. 
43. WWF-Brasil. Lições aprendidas sobre Zoneamento em Unidades de Conservação e no seu entorno: Comunidade de ensino e aprendizagem em Planejamento de Unidades de Conservação. In Escola Latino Americana de Áreas Protegidas (ELAP); WWF-Brasil: Brasília, Distrito Federal, Brazil, 2015; ISBN 978-85-86440-97-7.

44. Brazil. Conselho Nacional do Meio Ambiente. In Resolução CONAMA nº. 428, de 17 de Dezembro de 2010; Diário Oficial da União: Brasília, Brazil, 2010.

45. Brazil. Conselho Nacional do Meio Ambiente. In Resolução CONAMA nº. 473, de 11 de Dezembro de 2015; Diário Oficial da União: Brasília, Brazil, 2015.

46. Project MapBiomas Collection 4.0 of Brazilian Land Cover \& Use Map Series. Available online: https: //code.earthengine.google.com/accept_repo=users/mapbiomas/user-toolkit (accessed on 15 September 2019).

47. De Brito, B.N.; da Silva, E.B. Análise multitemporal de uso e cobertura da terra na Reserva da Biosfera do Cerrado. Ateliê Geográfico 2019, 13, 73-91. [CrossRef]

48. Bonanomi, J.; Tortato, F.R.; de Souza, R.G.; Penha, J.M.; Bueno, A.S.; Peres, C.A. Protecting forests at the expense of native grasslands: Land-use policy encourages open-habitat loss in the Brazilian cerrado biome. Perspect. Ecol. Conserv. 2019, 17, 26-31. [CrossRef]

49. Diniz, C.; Cortinhas, L.; Nerino, G.; Rodrigues, J.; Sadeck, L.; Adami, M.; Souza-Filho, P.W.M. Brazilian Mangrove Status: Three Decades of Satellite Data Analysis. Remote Sens. 2019, 11, 808. [CrossRef]

50. Mas, J.-F.; de Vasconcelos, R.; Franca-Rocha, W. Analysis of High Temporal Resolution Land Use/Land Cover Trajectories. Land 2019, 8, 30. [CrossRef]

51. MapBiomas. MapBiomas General "Handbook". In Algorithm Theoretical Basis Document (ATBD); Collection 4.0. Version 2.0.; MapBiomas: São Paulo, Brazil, 2019.

52. Pontius, R.G.; Millones, M. Death to Kappa: Birth of quantity disagreement and allocation disagreement for accuracy assessment. Int. J. Remote Sens. 2011, 32, 4407-4429. [CrossRef]

53. Rouse, J.W.; Haas, R.H.; Schell, J.A.; Deering, D.W. Monitoring Vegetation Systems in the Great Okains with ERTS. Third Earth Resour. Technol. Satell. Symp. 1973, 1, 325-333.

54. Huete, A.; Didan, K.; Miura, T.; Rodriguez, E.; Gao, X.; Ferreira, L. Overview of the radiometric and biophysical performance of the MODIS vegetation indices. Remote Sens. Environ. 2002, 83, 195-213. [CrossRef]

55. Soudani, K.; le Maire, G.; Dufrêne, E.; François, C.; Delpierre, N.; Ulrich, E.; Cecchini, S. Evaluation of the onset of green-up in temperate deciduous broadleaf forests derived from Moderate Resolution Imaging Spectroradiometer (MODIS) data. Remote Sens. Environ. 2008, 112, 2643-2655. [CrossRef]

56. Solano, R.; Didan, K.; Jacobson, A.; Huete, A. MODIS Vegetation Index User's Guide (MOD13 Series); Vegetation Index and Phenology Lab, The University of Arizona: Tucson, AZ, USA, 2010.

57. Gorelick, N.; Hancher, M.; Dixon, M.; Ilyushchenko, S.; Thau, D.; Moore, R. Google Earth Engine: Planetary-scale geospatial analysis for everyone. Remote Sens. Environ. 2017, 202, 18-27. [CrossRef]

58. Vermote, E.F.; El Saleous, N.Z.; Justice, C.O. Atmospheric correction of MODIS data in the visible to middle infrared: First results. Remote Sens. Environ. 2002, 83, 97-111. [CrossRef]

59. Bellón, B.; Bégué, A.; Lo Seen, D.; de Almeida, C.A.; Simões, M. A Remote Sensing Approach for Regional-Scale Mapping of Agricultural Land-Use Systems Based on NDVI Time Series. Remote Sens. 2017, 9, 600. [CrossRef]

60. Chen, J.; Jönsson, P.; Tamura, M.; Gu, Z.; Matsushita, B.; Eklundh, L. A simple method for reconstructing a high-quality NDVI time-series data set based on the Savitzky-Golay filter. Remote Sens. Environ. 2004, 91, 332-344. [CrossRef]

61. Markham, B.L.; Storey, J.C.; Williams, D.L.; Irons, J.R. Landsat sensor performance: History and current status. IEEE Trans. Geosci. Remote Sens. 2004, 42, 2691-2694. [CrossRef]

62. Dwyer, J.L.; Roy, D.P.; Sauer, B.; Jenkerson, C.B.; Zhang, H.K.; Lymburner, L. Analysis ready data: Enabling analysis of the Landsat archive. Remote Sens. 2018, 10, 1363. [CrossRef]

63. USGS EROS. Landsat Collection 1 Level 1 Product Definition (LSDS-1656); Version 2.0.; EROS: Sioux Falls, SD, USA, 2019.

64. Micijevic, E.; Haque, M.O; Mishra, N. Radiometric calibration updates to the Landsat collection. In Proceedings of the Earth Observing Systems XXI, San Diego, CA, USA, 19 September 2016; Volume 9972.

65. Lewis, H.G.; Brown, M. A generalized confusion matrix for assessing area estimates from remotely sensed data. Int. J. Remote Sens. 2001, 22, 3223-3235. [CrossRef] 
66. Pontius, R.G., Jr.; Cheuk, M.L. A generalized cross-tabulation matrix to compare soft-classified maps at multiple resolutions. Int. J. Geogr. Inf. Sci. 2006, 20, 1-30. [CrossRef]

67. Schmidt, M. The Sankey diagram in energy and material flow management: Part I: History. J. Ind. Ecol. 2008, 12, 82-94. [CrossRef]

68. Cuba, N. Research note: Sankey diagrams for visualizing land cover dynamics. Landsc. Urban Plan. 2015, 139, 163-167. [CrossRef]

69. Gandrud, C.; Allaire, J.J.; Russell, K.; Lewis, B.W.; Kuo, K.; Sese, C.; Ellis, P.; Owen, J.; Rogers, J. NetworkD3: D3 JavaScript Network Graphs. 2017. Available online: https://CRAN.R-project.org/package=networkD3 (accessed on 15 December 2019).

70. R Core Team. R: A Language and Environment for Statistical Computing; R Foundation for Statistical Computing: Vienna, Austria, 2019.

71. Gamon, J.A.; Huemmrich, K.F.; Stone, R.S.; Tweedie, C.E. Spatial and temporal variation in primary productivity (NDVI) of coastal Alaskan tundra: Decreased vegetation growth following earlier snowmelt. Remote Sens. Environ. 2013, 129, 144-153. [CrossRef]

72. Gao, Q.; Zhu, W.; Schwartz, M.W.; Ganjurjav, H.; Wan, Y.; Qin, X.; Ma, X.; Williamson, M.A.; Li, Y. Climatic change controls productivity variation in global grasslands. Sci. Rep. 2016, 6. [CrossRef] [PubMed]

73. Pettorelli, N.; Gaillard, J.-M.; Mysterud, A.; Duncan, P.; Chr. Stenseth, N.; Delorme, D.; Van Laere, G.; Toïgo, C.; Klein, F. Using a proxy of plant productivity (NDVI) to find key periods for animal performance: The case of roe deer. Oikos 2006, 112, 565-572. [CrossRef]

74. Pricope, N.G.; Gaughan, A.E.; All, J.D.; Binford, M.W.; Rutina, L.P. Spatio-temporal analysis of vegetation dynamics in relation to shifting inundation and fire regimes: Disentangling environmental variability from land management decisions in a Southern African Transboundary Watershed. Land 2015, 4, 627-655. [CrossRef]

75. Wang, J.; Rich, P.M.; Price, K.P.; Kettle, W.D. Relations between NDVI and tree productivity in the central Great Plains. Int. J. Remote Sens. 2004, 25, 3127-3138. [CrossRef]

76. Wen, L.; Yang, X.; Saintilan, N. Local climate determines the NDVI-based primary productivity and flooding creates heterogeneity in semi-arid floodplain ecosystem. Ecol. Model. 2012, 242, 116-126. [CrossRef]

77. Friedl, M.; Henebry, G.; Reed, B.; Huete, A.; White, M.; Morisette, J.; Nemani, R.; Zhang, X.; Myneni, R. Land surface phenology. A Community White Paper requested by NASA. 2006. Available online: https: //cce.nasa.gov/mtg2008_ab_presentations/Phenology_Friedl_whitepaper.pdf (accessed on 30 April 2020).

78. Zeng, L.; Wardlow, B.D.; Xiang, D.; Hu, S.; Li, D. A review of vegetation phenological metrics extraction using time-series, multispectral satellite data. Remote Sens. Environ. 2020, 237, 111511. [CrossRef]

79. Ding, Y.; Zhao, K.; Zheng, X.; Jiang, T. Temporal dynamics of spatial heterogeneity over cropland quantified by time-series NDVI, near infrared and red reflectance of Landsat 8 OLI imagery. Int. J. Appl. Earth Obs. Geoinf. 2014, 30, 139-145. [CrossRef]

80. Miranda, C.S.; Gamarra, R.M.; Mioto, C.L.; Silva, N.M.; Conceição Filho, A.P.; Pott, A. Analysis of the landscape complexity and heterogeneity of the Pantanal wetland. Braz. J. Biol. 2018, 78, 318-327. [CrossRef]

81. Rocchini, D.; Delucchi, L.; Bacaro, G.; Cavallini, P.; Feilhauer, H.; Foody, G.M.; He, K.S.; Nagendra, H.; Porta, C.; Ricotta, C.; et al. Calculating landscape diversity with information-theory based indices: A GRASS GIS solution. Ecol. Inform. 2013, 17, 82-93. [CrossRef]

82. Pettorelli, N. The Normalized Difference Vegetation Index; Oxford University Press: Oxford, UK, 2013; ISBN 978-0-19-969316-0.

83. Oindo, B.O.; Skidmore, A.K. Interannual variability of NDVI and species richness in Kenya. Int. J. Remote Sens. 2002, 23, 285-298. [CrossRef]

84. Riera, J.L.; Magnuson, J.J.; Castle, J.R.V.; MacKenzie, M.D. Analysis of large-scale spatial heterogeneity in vegetation indices among North American landscapes. Ecosystems 1998, 1, 268-282. [CrossRef]

85. Corrêa, C.C.; Pimenta, M.; Dutra, S.L.; Marco Júnior, P. Utilização do NDVI na avaliação da resposta de besouros herbívoros à complexidade e heterogeneidade ambiental em diferentes escalas no Bioma cerrado. In Proceedings of the Anais XV Simpósio Brasileiro de Sensoriamento Remoto. INPE, Curitiba, Paraná, Brazil, 30 April-5 May 2011; Volume 30, pp. 3103-3110.

86. Gamarra, R.M.; Teixeira-Gamarra, M.C.; Carrijo, M.G.G.; Paranhos Filho, A.C. Uso do NDVI na análise da estrutura da vegetação e efetividade da proteção de Unidade de Conservação no Cerrado. Raega-O Espaço Geográfico em Análise 2016, 37, 307-332. [CrossRef] 
87. Cava, M.G.B.; Pilon, N.A.L.; Ribeiro, M.C.; Durigan, G. Abandoned pastures cannot spontaneously recover the attributes of old-growth savannas. J. Appl. Ecol. 2018, 55, 1164-1172. [CrossRef]

88. Spera, S.A.; Galford, G.L.; Coe, M.T.; Macedo, M.N.; Mustard, J.F. Land-use change affects water recycling in Brazil's last agricultural frontier. Glob. Chang. Biol. 2016, 22, 3405-3413. [CrossRef]

89. Zalles, V.; Hansen, M.C.; Potapov, P.V.; Stehman, S.V.; Tyukavina, A.; Pickens, A.; Song, X.-P.; Adusei, B.; Okpa, C.; Aguilar, R.; et al. Near doubling of Brazil's intensive row crop area since 2000. Proc. Natl. Acad. Sci. USA 2019, 116, 428-435. [CrossRef]

90. Bernard, E.; Penna, L.A.O.; Araújo, E. Downgrading, downsizing, degazettement, and reclassification of protected areas in Brazil. Conserv. Biol. 2014, 28, 939-950. [CrossRef]

91. MMA; Ministério do Meio Ambiente. Mapeamento do Uso e Cobertura do Cerrado: Projeto Terra Class Cerrado 2013; MMA: Brasília, Distrito Federal, Brazil, 2015; 67p, ISBN 978-85-7738-255-2.

92. Bustamante, M.M.d.C.; Nardoto, G.B.; Pinto, A.S.; Resende, J.C.F.; Takahashi, F.S.C.; Vieira, L.C.G. Potential impacts of climate change on biogeochemical functioning of Cerrado ecosystems. Braz. J. Biol. 2012, 72, 655-671. [CrossRef]

93. Oliveira-Filho, A.T.; Ratter, J.A. Vegetation physiognomies and woody flora of the cerrado biome. In The Cerrados of Brazil: Ecology and Natural History of a Neotropical Savanna; Oliveira, P., Marquis, R., Eds.; Columbia University Press: New York, NY, USA, 2002; pp. 91-120.

94. Passos, F.B.; Marimon, B.S.; Phillips, O.L.; Morandi, P.S.; das Neves, E.C.; Elias, F.; Reis, S.M.; de Oliveira, B.; Feldpausch, T.R.; Junior, B.H.M. Savanna turning into forest: Concerted vegetation change at the ecotone between the Amazon and "Cerrado" biomes. Braz. J. Bot. 2018, 41, 611-619. [CrossRef]

95. Arvor, D.; Meirelles, M.; Dubreuil, V.; Bégué, A.; Shimabukuro, Y.E. Analyzing the agricultural transition in Mato Grosso, Brazil, using satellite-derived indices. Appl. Geogr. 2012, 32, 702-713. [CrossRef]

96. Spera, S. Agricultural Intensification Can Preserve the Brazilian Cerrado: Applying Lessons From Mato Grosso and Goiás to Brazil's Last Agricultural Frontier. Trop. Conserv. Sci. 2017, 10, 194008291772066. [CrossRef]

97. Woodcock, C.E.; Loveland, T.R.; Herold, M.; Bauer, M.E. Transitioning from change detection to monitoring with remote sensing: A paradigm shift. Remote Sens. Environ. 2020, 238. [CrossRef]

98. Lausch, A.; Blaschke, T.; Haase, D.; Herzog, F.; Syrbe, R.-U.; Tischendorf, L.; Walz, U. Understanding and quantifying landscape structure-A review on relevant process characteristics, data models and landscape metrics. Ecol. Model. 2015, 295, 31-41. [CrossRef]

99. Pettorelli, N.; to Bühne, H.; Tulloch, A.; Dubois, G.; Macinnis-Ng, C.; Queirós, A.M.; Keith, D.A.; Wegmann, M.; Schrodt, F.; Stellmes, M.; et al. Satellite remote sensing of ecosystem functions: Opportunities, challenges and way forward. Remote Sens. Ecol. Conserv. 2018, 4, 71-93. [CrossRef]

100. Requena-Mullor, J.M.; López, E.; Castro, A.J.; Cabello, J.; Virgós, E.; González-Miras, E.; Castro, H. Modeling spatial distribution of European badger in arid landscapes: An ecosystem functioning approach. Landsc. Ecol. 2014, 29, 843-855. [CrossRef]

101. Alcaraz-Segura, D.; Lomba, A.; Sousa-Silva, R.; Nieto-Lugilde, D.; Alves, P.; Georges, D.; Vicente, J.R.; Honrado, J.P. Potential of satellite-derived ecosystem functional attributes to anticipate species range shifts. Int. J. Appl. Earth Obs. Geoinf. 2017, 57, 86-92. [CrossRef]

102. Alleaume, S.; Dusseux, P.; Thierion, V.; Commagnac, L.; Laventure, S.; Lang, M.; Féret, J.-B.; Hubert-Moy, L.; Luque, S. A generic remote sensing approach to derive operational essential biodiversity variables (EBVs) for conservation planning. Methods Ecol. Evol. 2018, 9, 1822-1836. [CrossRef]

103. Vihervaara, P.; Auvinen, A.P.; Mononen, L.; Törmä, M.; Ahlroth, P.; Anttila, S.; Böttcher, K.; Forsius, M.; Heino, J.; Heliölä, J.; et al. How Essential Biodiversity Variables and remote sensing can help national biodiversity monitoring. Glob. Ecol. Conserv. 2017, 10, 43-59. [CrossRef]

104. Pereira, H.M.; Ferrier, S.; Walters, M.; Geller, G.N.; Jongman, R.H.G.; Scholes, R.J.; Bruford, M.W.; Brummitt, N.; Butchart, S.H.M.; Cardoso, A.C.; et al. Essential biodiversity variables. Science 2013, 339, 277-278. [CrossRef] 
105. Pettorelli, N.; Wegmann, M.; Skidmore, A.; Mücher, S.; Dawson, T.P.; Fernandez, M.; Lucas, R.; Schaepman, M.E.; Wang, T.; O'Connor, B.; et al. Framing the concept of satellite remote sensing essential biodiversity variables: Challenges and future directions. Remote Sens. Ecol. Conserv. 2016, 2, 122-131. [CrossRef]

106. De Araujo Barbosa, C.C.; Atkinson, P.M.; Dearing, J.A. Remote sensing of ecosystem services: A systematic review. Ecol. Indic. 2015, 52, 430-443. [CrossRef]

107. Pasetto, D.; Arenas-Castro, S.; Bustamante, J.; Casagrandi, R.; Chrysoulakis, N.; Cord, A.F.; Dittrich, A.; Domingo-Marimon, C.; El Serafy, G.; Karnieli, A.; et al. Integration of satellite remote sensing data in ecosystem modelling at local scales: Practices and trends. Methods Ecol. Evol. 2018, 9, 1810-1821. [CrossRef]

108. Randin, C.F.; Ashcroft, M.B.; Bolliger, J.; Cavender-Bares, J.; Coops, N.C.; Dullinger, S.; Dirnböck, T.; Eckert, S.; Ellis, E.; Fernández, N.; et al. Monitoring biodiversity in the Anthropocene using remote sensing in species distribution models. Remote Sens. Environ. 2020, 239. [CrossRef]

109. He, K.S.; Bradley, B.A.; Cord, A.F.; Rocchini, D.; Tuanmu, M.-N.; Schmidtlein, S.; Turner, W.; Wegmann, M.; Pettorelli, N. Will remote sensing shape the next generation of species distribution models? Remote Sens. Ecol. Conserv. 2015, 1, 4-18. [CrossRef]

110. Remelgado, R.; Wegmann, M.; Safi, K. rsmove-An r package to bridge remote sensing and movement ecology. Methods Ecol. Evol. 2019, 10, 1212-1221. [CrossRef]

111. Martín-López, B.; Palomo, I.; García-Llorente, M.; Iniesta-Arandia, I.; Castro, A.J.; Del Amo, D.G.; Gómez-Baggethun, E.; Montes, C. Delineating boundaries of social-ecological systems for landscape planning: A comprehensive spatial approach. Land Use Policy 2017, 66, 90-104. [CrossRef]

112. De Oliveira Roque, F.; Uehara-Prado, M.; Valente-Neto, F.; Quintero, J.M.O.; Ribeiro, K.T.; Martins, M.B.; de Lima, M.G.; Souza, F.L.; Fischer, E.; da Silva, U.L., Jr.; et al. A network of monitoring networks for evaluating biodiversity conservation effectiveness in Brazilian protected areas. Perspect. Ecol. Conserv. 2018, 16, 177-185. [CrossRef]

113. Claverie, M.; Ju, J.; Masek, J.G.; Dungan, J.L.; Vermote, E.F.; Roger, J.-C.; Skakun, S.V.; Justice, C. The Harmonized Landsat and Sentinel-2 surface reflectance data set. Remote Sens. Environ. 2018, 219, 145-161. [CrossRef]

114. Wulder, M.A.; Loveland, T.R.; Roy, D.P.; Crawford, C.J.; Masek, J.G.; Woodcock, C.E.; Allen, R.G.; Anderson, M.C.; Belward, A.S.; Cohen, W.B.; et al. Current status of Landsat program, science, and applications. Remote Sens. Environ. 2019, 225, 127-147. [CrossRef]

115. Roy, D.P.; Kovalskyy, V.; Zhang, H.K.; Vermote, E.F.; Yan, L.; Kumar, S.S.; Egorov, A. Characterization of Landsat-7 to Landsat-8 reflective wavelength and normalized difference vegetation index continuity. Remote Sens. Environ. 2016, 185, 57-70. [CrossRef]

116. Steven, M.D.; Malthus, T.J.; Baret, F.; Xu, H.; Chopping, M.J. Intercalibration of vegetation indices from different sensor systems. Remote Sens. Environ. 2003, 88, 412-422. [CrossRef]

117. Li, P.; Jiang, L.; Feng, Z. Cross-comparison of vegetation indices derived from Landsat-7 enhanced thematic mapper plus (ETM+) and Landsat-8 operational land imager (OLI) sensors. Remote Sens. 2014, 6, 310-329. [CrossRef]

118. Ke, Y.; Im, J.; Lee, J.; Gong, H.; Ryu, Y. Characteristics of Landsat 8 OLI-derived NDVI by comparison with multiple satellite sensors and in-situ observations. Remote Sens. Environ. 2015, 164, 298-313. [CrossRef]

119. INMET. Banco de Dados Meteorológicos para Ensino e Pesquisa. Instituto Nacional de Meteorologia. Available online: http://www.inmet.gov.br/portal/index.php?r=bdmep/bdmep (accessed on 20 September 2019).

120. QGIS Development Team. Open Source Geospatial Foundation Project; QGIS 2.18. Geographic Information System User Guide. 2019. Available online: https://docs.qgis.org/2.18/pdf/en/QGIS-2.18-UserGuide-en.pdf (accessed on 29 April 2020).

121. Hänsel, S.; Schucknecht, A.; Matschullat, J. The Modified Rainfall Anomaly Index (mRAI)—is this an alternative to the Standardised Precipitation Index (SPI) in evaluating future extreme precipitation characteristics? Theor. Appl. Clim. 2016, 123, 827-844. [CrossRef]

(C) 2020 by the authors. Licensee MDPI, Basel, Switzerland. This article is an open access article distributed under the terms and conditions of the Creative Commons Attribution (CC BY) license (http://creativecommons.org/licenses/by/4.0/). 